UNIVERSIDADE DE SÃO PAULO

FACULDADE DE ZOOTECNIA E ENGENHARIA DE ALIMENTOS

ROULBER CARVALHO GOMES DA SILVA

SELEÇÃO ASSISTIDA POR MARCADORES

GENÉTICOS DE CARACTERISTICAS DE CARCAÇA EM BOVINOS DA RAÇA NELORE

Pirassununga - SP 
ROULBER CARVALHO GOMES DA SILVA

\section{SELEÇÃO ASSISTIDA POR MARCADORES GENÉTICOS DE CARACTERISTICAS DE CARCAÇA EM BOVINOS DA RAÇA NELORE}

Tese apresentada à Faculdade de Zootecnia e Engenharia de Alimentos da Universidade de São Paulo, como parte dos requisitos para a obtenção do Título de Doutor em Zootecnia.

Área de Concentração: Qualidade e Produtividade Animal

Orientador: Prof. Dr. José Bento Sterman Ferraz

Pirassununga - SP

2012 
Dados Internacionais de Catalogação na Publicação

Serviço de Biblioteca e Informação da Faculdade de Zootecnia e Engenharia de Alimentos da Universidade de São Paulo

Silva, Roulber Carvalho Gomes da
S586s Seleção assistida por marcadores genéticos de características de carcaça em bovinos da raça Nelore / Roulber Carvalho Gomes da Silva. -- Pirassununga, 2012. $79 \mathrm{f}$.

Tese (Doutorado) -- Faculdade de Zootecnia e

Engenharia de Alimentos - Universidade de São Paulo. Departamento de Ciências Básicas.

Área de Concentração: Qualidade e Produtividade Animal.

Orientador: Prof. Dr. José Bento Sterman Ferraz.

1. Acurácia 2. Herdabilidade 3. SNP 4. Ultrassom

5. Valor genético molecular. I. Título. 
Aos mens queridos pais e irmãos que tanto me incentivaram, dedico este trabalho. 
À minha amiga, companheira, incentivadora e mew grande amor, Patricia, agradeço a cada dia por você estar ao men lado e fazer parte dessa história. 


\section{Agradecimentos}

Ao meu Deus por guiar meus passos e sempre iluminar minhas escolhas.

Aos meus pais Hélio e Vera e aos meus irmãos Mi e Jô por compreenderem as minhas ausências do convívio familiar e que sempre me incentivaram a alcançar meus objetivos.

Às minhas avós Lucia e Marinalva, à tia Isabel e minha prima Mariana pela constante torcida.

À Dona Alice Marafon, ao Sr. Ari Porciuncula e toda a família que me adotou em Santa Catarina.

Ao Professor José Bento Sterman Ferraz pela orientação e, principalmente, pela amizade nesses anos de convívio.

Aos Professores Joanir, Gerson, Júlio e Flávio pelo convívio, sugestões e aprendizado.

À amiga e professora Fernanda Marcondes Rezende pelas sugestões nesse trabalho e pela amizade.

À Elisângela pela paciência e toda ajuda nesses anos.

A todos os amigos do GMAB, Adalfredo, Cucco, Gerson, Jane, Luis Fernando, Marina, Manicardi, Rodrigo, Miguel, Mirele, Preto, Priscila, Minos, Aline, Chico e tantos outros que tive a oportunidade de conviver.

Aos amigos da Merial, Henry Berger, Guilherme Gallerani, Fernanda Ambrosino, Edson Bordin, José Morgado e Marcos Malacco, agradeço pela confiança e por todo aprendizado durante esses anos de convivência.

Aos funcionários da FZEA/USP, em especial a Layla, Alecsandra, Gilson e Arnaldo, pelo apoio constante.

Aos funcionários da biblioteca da FZEA/USP, em especial ao Girlei Lima pela disponibilidade de ajudar sempre.

À Merial Saúde Animal por possibilitar a realização desse trabalho.

À Agro-Pecuária CFM Ltda. por disponibilizar os dados aqui analisados.

À Universidade de São Paulo, que por meio da FZEA proporcionou a realização desse trabalho.

A todos aqueles que por ventura não tenham sido citados e que de alguma maneira contribuíram para a realização desse trabalho fica aqui meu sincero agradecimento. 


\section{Resumo}

SILVA, R.C.G. Seleção assistida por marcadores genéticos de características de carcaça em bovinos da raça Nelore. 2012. 79 f. Tese (Doutorado) Faculdade de Zootecnia e Engenharia de Alimentos, Universidade de São Paulo, Pirassununga, 2012.

A pecuária de corte brasileira tem sofrido grande pressão devido às questões ambientais, às exigências dos mercados consumidores por carne de qualidade e rígidos padrões sanitários. Esses fatores aumentam a importância da melhoria da eficiência produtiva da pecuária de corte. A proposta do presente trabalho foi avaliar o efeito da inclusão dos valores genéticos moleculares, de um painel de marcadores genéticos comerciais (Perfil IGENITY ${ }^{\circledR}$ Nelore V3) na seleção de animais da raça Nelore. Foram utilizados dados de 9.749 animais da raça Nelore mensurados para área de olho de lombo, espessura de gordura subcutânea e espessura de gordura na picanha e 39.687 animais na matriz de parentesco. Dois modelos de análise foram utilizados. $O$ modelo de análise unicaracterística em que apenas os parâmetros genéticos do fenótipo foram estimados e o modelo bi-característica em que os valores genéticos moleculares de 3.033 animais foram incluídos como característica correlacionada. A inclusão dos valores genéticos moleculares no modelo aumentou as acurácias das estimativas dos valores genéticos preditos dos animais genotipados, principalmente dos machos jovens. As analises dos conflitos de seleção demonstraram maiores divergências nos touros e machos jovens que tiveram seus genótipos definidos. A taxa de ganho genético anual com a inclusão dos valores genéticos moleculares no modelo foi aumentada em 2,4\% para área de olho de lombo, 0,9\% para espessura de gordura subcutânea e 1,9\% para espessura de gordura na picanha. Esses resultados demonstram que a utilização dos valores genéticos moleculares, mesmo quando oriundos de painéis de marcadores de DNA de baixa densidade, pode contribuir na seleção de animais superior mérito genético e, além de promover aumento nos ganhos genéticos dos programas de melhoramento genético da raça Nelore.

Palavras-chave: acurácia, herdabilidade, SNP, ultrassom, valor genético molecular. 


\section{ABSTRACT}

SILVA, R.C.G. Genetic marker assisted selection of carcass traits in Nellore cattle. 2012. 79 f. PhD Thesis - Faculdade de Zootecnia e Engenharia de Alimentos, Universidade de São Paulo, Pirassununga, 2012.

The Brazilian beef cattle chain is suffering a huge pressure due to environmental issues, the demand of consumer markets for meat quality and strict sanitary standards of the international market. These factors increase the importance of improving productive efficiency of beef cattle. The proposal of this study was to evaluate the effect of inclusion of the molecular breeding values of a commercial panel of genetic markers (Nellore Profile IGENITY ${ }^{\circledR}$ V3) in the genetic selection of Nellore cattle. Data of 9,749 animals measured for ribeye area, fat thickness and rump fat thickness were used in this study, with a relationship matrix compound of 39,687 animals. Two models of analysis were performed. Single trait model was performed only for each observed phenotypes and two-trait model was performed phenotypes and molecular breeding values of 3,033 animals as a correlated trait. The inclusion of molecular information in genetic evaluation provided increases on the accuracies of predicted breeding values of genotyped animals and, mainly, for replacement young bulls. The divergences of selection for $20 \%$ best animals classified by 1 -trait breeding values and 2 -trait breeding values demonstrated highest divergence for sires and replacement young bulls. The genetic change rate on the 2-trait model increased $2,4 \%$ for ribeye area, 0,9 for fat thickness and $1,9 \%$ for rump fat thickness. These results demonstrated that the inclusion of molecular breeding values, even when estimated from low density genetic markers panels, on animal breeding evaluations can contribute on the selection of best genetic merit animals and increase of genetic change rate on animal breeding programs for Nellore cattle.

Keywords: accuracy, heritability; SNP; ultrasound, molecular breeding values. 


\section{Sumário}

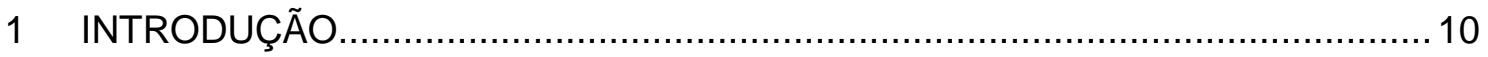

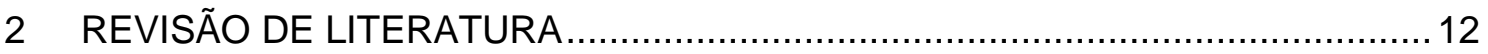

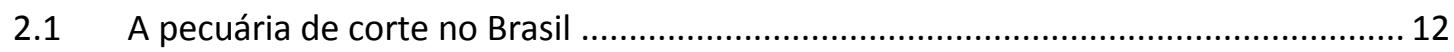

2.2 Seleção Assistida por Marcadores Genéticos .............................................................. 13

2.3 Ultrassonografia na avaliação de precocidade de acabamento e

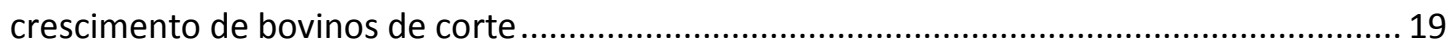

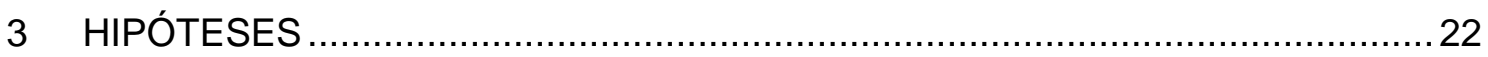

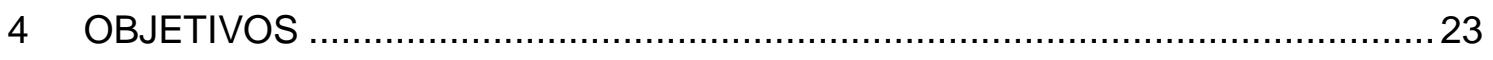

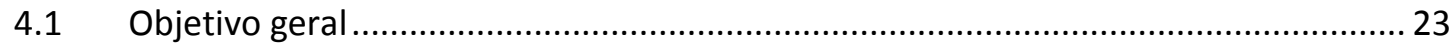

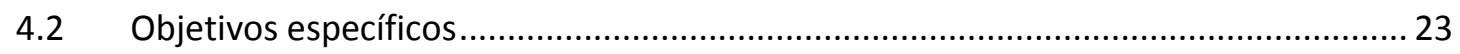

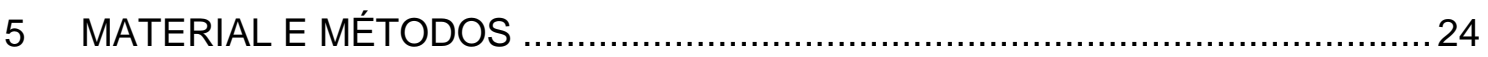

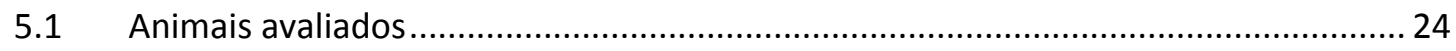

5.2 Metodologia de coleta de dados de carcaça por ultrassom ...................................... 25

5.3 Coleta de amostras biológicas, extração de DNA, genotipagem e determinação dos valores genéticos moleculares (Perfil IGENITY ${ }^{\circledR}$ Nelore V3) ...................... 27

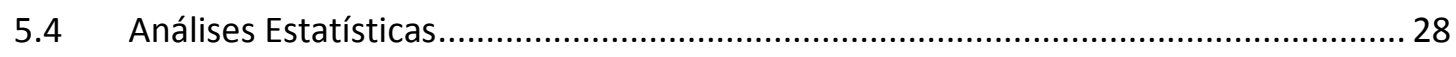

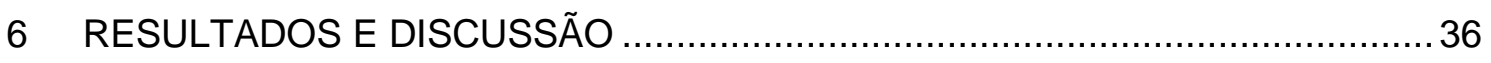

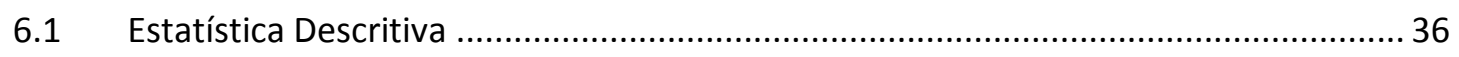

6.2 Parâmetros genéticos e componentes de (co) variância para as características de carcaça ................................................................................................. 42

6.3 Valores genéticos preditos e acurácias ................................................................... 49

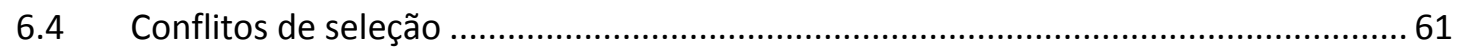

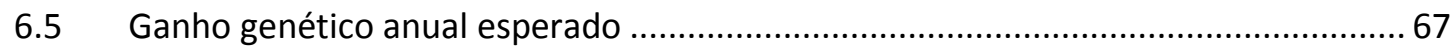

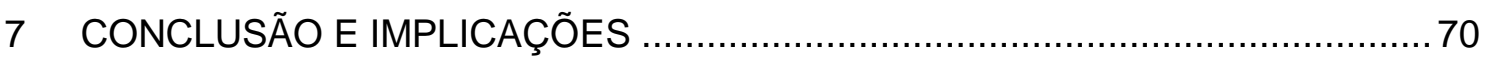


8 REFERÊNCIAS BIBLIOGRÁFICAS 


\section{INTRODUÇÃO}

A pecuária de corte brasileira tem sofrido grande pressão da sociedade devido à ligação da atividade com a abertura de fronteiras agrícolas, desmatamento de florestas e com a emissão de metano pelo processo de digestão de alimentos dos bovinos. Além disso, existe a necessidade de atender às demandas dos mercados internos e externos por carne de qualidade, com origem certificada e seguindo rígidos padrões sanitários. Esses fatores colocam toda a cadeia produtiva da carne frente a grandes desafios, tornando-se indispensável o desenvolvimento de tecnologias que possam melhorar os índices produtivos e auxiliar os criadores e a indústria a atender as exigências dos mercados consumidores.

O desempenho de um animal ou de um rebanho é influenciado por vários fatores ambientais (ex: nutrição, manejo, sanidade, etc.), pela genética e pela interação da genética com o ambiente. A genética é um dos fatores importantes para a maximização dos ganhos na produtividade e para isso é indispensável a utilização de estratégias adequadas de seleção e acasalamento dos animais de acordo com os objetivos de cada rebanho.

Tradicionalmente, no Brasil, os programas de melhoramento genético de bovinos de corte priorizam características de crescimento e circunferência escrotal, entretanto, nos últimos anos tem-se dado maior importância para características reprodutivas e de carcaça, entretanto, essas são características de manifestação tardia, ou seja, um animal será avaliado para as características de carcaça medidas por ultrassom entre os 18 e 20 meses, dependendo do manejo adotado pela fazenda.

Com o desenvolvimento das tecnologias de genotipagem, surgiu a possibilidade da utilização da seleção assistida por marcadores genéticos. Essa ferramenta tem por objetivo aumentar a acurácia de seleção, principalmente para as características com expressão fenotípica tardia ou de difícil mensuração. A seleção assistida por marcadores pode alterar a taxa de mudança genética em um rebanho, pois além de aumentar a acurácia de seleção de uma característica, pode diminuir os erros de predição do valor genético de animais jovens, viabilizando a utilização desses indivíduos como 
reprodutores com maior intensidade, diminuindo o intervalo de gerações da população.

Dessa forma, a associação dos marcadores genéticos com a genética quantitativa para a seleção de animais de alto mérito genético para características relacionadas à qualidade de carcaça, torna-se fator importante para os programas de melhoramento genético de bovinos de corte, dando subsídios aos produtores no momento de selecionar os reprodutores que serão pais da próxima geração.

A proposta do presente trabalho foi avaliar o efeito da inclusão dos valores genéticos moleculares, de um painel de marcadores genéticos comerciais (Perfil IGENITY® Nelore V3) desenvolvido para a raça Nelore, na seleção de características de carcaça mensuradas por ultrassom em bovinos da raça Nelore. 


\section{REVISÃO DE LITERATURA}

\subsection{A pecuária de corte no Brasil}

O agronegócio brasileiro faturou cerca de $\mathrm{R} \$ 942$ bilhões no ano de 2011, ou seja, 22,7\% do produto interno bruto (PIB) no ano de 2011 (CEPEAUSP, 2012). A pecuária de corte brasileira desempenha papel fundamental na composição do PIB do país e é a maior cadeia produtiva do agronegócio brasileiro, representando faturamento de mais de $R \$ 50$ bilhões por ano e oferecendo cerca de 7,5 milhões de empregos (ABIEC, 2012).

O Brasil possui o maior rebanho comercial do mundo, com cerca de 209,5 milhões de cabeças (IBGE, 2011) e é o segundo maior produtor mundial de carne bovina com cerca de 9,1 milhões de toneladas equivalente-carcaça, ficando atrás apenas dos Estados Unidos em volume produzido (ABIEC, 2012). Além disso, foi o segundo maior exportador de carne bovina do mundo com cerca 1,32 milhões de toneladas equivalentecarcaça, ficando atrás apenas da Austrália (ANUALPEC, 2012; USDA, 2012).

Estima-se que cerca de $80 \%$ do rebanho brasileiro seja constituído por animais de raças zebuínas ou azebuadas, dos quais $90 \%$ sejam da raça Nelore (ABCZ, 2011), porém no sul do país a maioria do rebanho é formada por animais de raças taurinas e seus cruzamentos, principalmente nos estados do Rio Grande do Sul e Santa Catarina (FERRAZ; FELICIO, 2010). O sistema de produção de carne bovina predominante no Brasil é a produção a pasto (em torno de 172 milhões de ha de pastagens), sendo que dos 39,5 milhões de cabeças abatidas em 2011, apenas 3,4 milhões foram terminadas em confinamento (ABIEC, 2012).

Segundo Ferraz e Felicio (2010), há uma demanda de tourinhos de reposição da ordem de 450 a 500 mil tourinhos por ano, entretanto menos de $5 \%$ desses animais são selecionados com a utilização de DEPs (estimação do valor genético do animal) ou pelas informações de desempenho.

O potencial de produção da pecuária brasileira é imenso, porém seus índices de produtividade são bem inferiores aos dos principais concorrentes no mercado da carne, como é o caso da Austrália e dos EUA. Isso demonstra que existem oportunidades para o aumento da produtividade, inclusive na 
melhoria do potencial genético do rebanho brasileiro, principalmente na raça Nelore, através da seleção de animais geneticamente superiores pelos critérios de seleção adequados e pela utilização desses animais como reprodutores, promovendo a disseminação desse material genético nos rebanhos.

\subsection{Seleção Assistida por Marcadores Genéticos}

A seleção de indivíduos manifestando fenótipos específicos, que os diferem de seus contemporâneos, tem despertado o interesse do homem desde a domesticação das primeiras espécies. A essência dos programas de seleção animal tem sido a identificação de animais de elevado potencial genético pela estimação da melhor predição linear não viesada do valor genético, através da análise conjunta dos fenótipos observados e do pedigree (HENDERSON, 1975; OLIVEIRA; HENKES, 2002).

No moderno sistema produtivo de carne bovina, identifica-se a importância cada vez maior de produção eficiente, caracterizada pelo encurtamento do ciclo de produção e por produtos de melhor qualidade, obtidos pelo uso de animais geneticamente superiores em condições ambientais adequadas ao seu genótipo (BONILHA, 2003).

Segundo Euclides Filho (1999), a seleção é a escolha dos melhores indivíduos avaliados, os quais serão os responsáveis pela produção da próxima geração. É o processo decisório que indica quais animais de uma geração se tornarão pais da próxima geração.

De acordo com van der Werf (2006a), embora a idéia de seleção genética seja aumentar a proporção de alelos favoráveis na população, esses alelos não são observados de fato nos métodos clássicos de avaliação genética, já que seus valores são estimados através dos fenótipos observados e do pedigree. A seleção clássica quantitativa é baseada no efeito final de todos os genes em conjunto, sendo observado o desempenho fenotípico da característica a principal fonte de informação.

O termo Genômica foi utilizado pela primeira vez em 1986 para descrever a disciplina científica do mapeamento, seqüenciamento e análise das 
informações contidas no DNA (GREEN, 2010). As ferramentas moleculares tornaram-se disponíveis no fim dos anos 80 , e o seu marco principal foi o desenvolvimento da técnica de PCR (Polymerase Chain Reaction - reação em cadeia da polimerase) descrita por Mullis e Faloona (1987).

Os primeiros mapas de ligação na espécie bovina foram construídos com a utilização de algumas centenas de marcadores microssatélites e foram publicados por cientistas dos EUA e da Austrália no mesmo ano (BARENDSE et al., 1994; BISHOP et al., 1994). A disponibilidade dos primeiros mapas de ligação em bovinos permitiu aos pesquisadores a busca por regiões do genoma contendo polimorfismos que causavam diferenças no desempenho para características relevantes economicamente, dando início ao estudo dos chamados QTLS (Quantitative Trait Loci). Diversos estudos foram publicados descrevendo QTLs associados às características de interesse econômico em bovinos (FITZSIMMONS et al, 1998; POMP et al., 1997; STONE; KAPPES, 1996; WILKINS; DAVEY, 1997). Segundo Dekkers (2004), logo notou-se que a descoberta de QTLs era apenas o início do processo e seria necessário mais estudos e desenvolvimento de novas tecnologias para colocar esses resultados no campo.

O desenvolvimento da tecnologia para a detecção de marcadores SNP (Single Nucleotide Polymorphism), base molecular de vários outros tipos de marcadores genéticos, permitiu a descoberta de diversos SNPs em genes de interesse, também chamados de genes de efeito maior. Esses estudos foram desenvolvidos em rebanhos de raças taurinas e seus cruzamentos, geralmente, em animais criados em confinamentos (BUCHANAN et al., 2002; LAl et al., 1998; LIEFERS et al., 2004; NKRUMAH et al., 2004; NKRUMAH et al., 2005).

No Brasil foram realizados diversos estudos em raças zebuínas para verificar a variabilidade de SNPs previamente identificados em animais de raças taurinas e verificar suas associações com características economicamente relevantes, principalmente, nas raças Nelore e Gir (CURI et al, 2008; FERRAZ et al., 2009; LACORTE et al., 2006; PINTO et al., 2011; SOUZA et al., 2010).

A colaboração internacional envolvendo agências de diversos países, institutos de pesquisas, universidades e indústria permitiu grandes avanços 
tecnológicos nos estudos genéticos moleculares, trazendo metodologias de alto desempenho, alta acurácia e baixo custo para prospecção, caracterização e genotipagem de marcadores SNP (CAETANO, 2009; GREEN, 2010). Possibilitando a genotipagem de centenas a milhares de SNPs ao mesmo tempo, como por exemplo, as tecnologias Taqman ${ }^{\circledR}$ OpenArray ${ }^{\circledR}$, Sequenom iPlex Gold, 50k Illumina cheap e HD Illumina cheap.

Nos últimos anos, a expectativa de que a informação contida no DNA promova ganhos genéticos consideráveis direcionou muitos esforços em termos de pesquisa e desenvolvimento para o estudo da aplicação da genética molecular para a seleção de animais superiores (DEKKERS; HOSPITAL, 2002; MEUWISSEN; HAYES; GODDARD, 2001).

A informação dos efeitos de substituição alélica do marcador genético, em conjunto com a informação fenotípica e o pedigree, poderia ser usada para aumentar o ganho genético, pelo aumento da acurácia de seleção e pela redução do intervalo de gerações (SMITH; SIMPSON, 1986; SOLLER, 1978), já que o ganho genético é diretamente proporcional a acurácia de seleção e inversamente proporcional ao intervalo de gerações (BOURDON, 2000).

Entre os métodos propostos para estimar os efeitos dos alelos dos marcadores em características quantitativas está o procedimento de quadrados mínimos (GELDERMANN, 1975). Outro método baseado na teoria de índices de seleção que combinava as informações dos marcadores genéticos e as informações fenotípicas para obter as avaliações genéticas foi proposto por Soller (1978).

A utilização da teoria de modelos mistos para a estimação do efeito de substituição alélica, proposto por Fernando e Grossman (1989), possibilitou um ajuste mais adequado dos efeitos ambientais aos modelos, porém as simulações foram realizadas com dados de um único marcador. A expansão desse modelo para análise de diversos marcadores foi apresentada por Goddard (1992).

Muitos estudos teóricos e simulações foram conduzidos para avaliar estratégias para o uso das informações moleculares nos programas de seleção (DEKKERS, 2004). Alguns autores propuseram que a soma das estimativas do valor genético de cada marcador deveria ser incluída como efeito fixo ou efeito aleatório no modelo animal utilizado na avaliação genética (LANDE; 
THOMPSON, 1990; VAN ARENDONK et al., 1999; VILLANUEVA et al., 2002; WELLER, 2001).

Meuwissen, Hayes e Goddard (2001) propuseram a seleção genômica ampla, ou simplesmente, seleção genômica que é a seleção assistida por marcadores, porém com a utilização simultânea de milhares de marcadores distribuídos ao longo de todo o genoma. Essa metodologia já está sendo utilizada amplamente na seleção de touros jovens sem teste de progênie na Australia, Nova Zelândia, Holanda e Estados Unidos e tem aumentado a acurácia de seleção entre 20 e 67\%, dependendo da herdabilidade da característica, número de animais avaliados na população de referência e método estatístico utilizado para estimar os efeitos dos SNPs na população de referência (HARRIS; JOHNSON; SPELMAN, 2008; HAYES et al., 2009).

Diversas empresas têm desenvolvido e validado painéis de marcadores SNP para comercializar junto aos criadores. Geralmente os resultados são apresentados ao criador na forma de escores, estrelas (que são distribuídas de acordo com o número de alelos favoráveis de cada marcador genético) e/ou valores genéticos moleculares (VGM), que é a somatória dos efeitos de substituição alélica de cada marcador genético associado a uma determinada característica. Comumente o criador utiliza essas informações para a seleção de animais superiores, sem considerar outros critérios de seleção, como o valor genético fornecido pelos programas de avaliação genética (DEKKERS, 2004; MACNEIL et al., 2010). Entretanto, a melhor estratégia para a utilização dos valores genéticos moleculares é a análise em conjunto com as informações fenotípicas e com o pedigree, aumentando assim a acurácia de seleção dos animais quando comparado apenas com a seleção a partir dos valores genéticos moleculares (DEKKERS; HOSPITAL, 2002; SPANGLER; BERTRAND; REKAYA, 2007).

Utilizando dados simulados, Verrier (2001) relatou discreto aumento nas médias das acurácias $(0,8 \%$ a $3 \%)$ dos valores genéticos preditos em uma análise bi-característica utilizando fenótipos e informações moleculares quando comparado com as acurácias obtidas pela análise uni-característica.

Em estudo utilizando dados simulados foi apresentado aumento de $12,5 \%$ na acurácia de predição quando apenas $25 \%$ dos animais tinham genótipos e de $20,8 \%$ quando $100 \%$ dos animais tinham genótipos, 
considerando que a informação molecular explicava $10 \%$ da variação genética aditiva (SPANGLER; BERTRAND; REKAYA, 2007). Outros trabalhos com dados simulados demonstraram que o ganho genético obtido com a seleção assistida por marcadores é diretamente proporcional à proporção da variância genética explicada pelos marcadores genéticos (LANDE; THOMPSON, 1990; MEUWISSEN; GODDARD, 1996). Segundo Thallman et al. (2009), a proporção da variância genética aditiva explicada pelos marcadores genéticos pode ser calculada pela correlação genética aditiva da análise bi-característica elevada ao quadrado.

A incorporação dos valores genéticos moleculares no modelo para estimação dos valores genéticos como característica correlacionada foi proposta por Kachman (2008). Segundo o autor, para os valores genéticos moleculares serem altamente correlacionados com o valor genético real, é necessário que os efeitos de substituição alélica estimados para os marcadores genéticos captem parte da porção genética aditiva do valor genético real. Dessa forma será necessário estimar a correlação genética entre o valor genético molecular e a característica, os coeficientes de herdabilidade e a variância fenotípica dos marcadores.

MacNeil et al. 2010 utilizaram dados reais de escore de marmoreio, porcentagem de gordura intramuscular e valores genéticos moleculares de um painel de marcadores especifico para a raça Angus desenvolvido por IGENITY® e estimaram os componentes de (co) variância e parâmetros genéticos numa análise tri-característica, conforme sugerido por Kachman (2008). O coeficiente de herdabilidade dos valores genéticos moleculares foi de 0,98 e correlações genéticas entre os valores genéticos moleculares e os fenótipos foi de 0,38 e 0,80, respectivamente, para escore de marmoreio e percentagem de gordura intramuscular. Os autores relataram aumento de 0,12 para 0,18 na acurácia dos animais que não tinham progênie e tinham os valores genéticos moleculares como fonte de informação para a característica.

Tang et al. (2011) avaliaram o efeito da inclusão de valores genéticos moleculares na avaliação genética de animais da raça Angus do Canadá e relataram coeficientes de herdabilidade dos painéis de marcadores entre $0,84 \mathrm{e}$ 0,92 . As correlações genéticas encontradas foram de 0,61 para peso ao nascimento, 0,39 para peso a desmama, 0,14 para efeito materno de peso a 
desmama, 0,38 para peso aos 12 meses de idade, 0,57 para peso adulto e 0,54 para perímetro escrotal.

Os primeiros resultados da inclusão das informações moleculares em animais da raça Nelore foram obtidos a partir de análise octa-característica com os fenótipos e valores genéticos moleculares de peso a desmama, ganho de peso pós-desmama, perímetro escrotal aos 18 meses e musculosidade. As acurácias dos animais jovens com menos de 02 anos de idade e genotipados tiveram um incremento de aproximadamente $45 \%$ para peso a desmama e musculosidade, $30 \%$ para ganho de peso pós-desmama e 18\% para perímetro escrotal aos 18 meses (informação verbal) *.

Estudo semelhante na raça Nelore, publicado por Lôbo et al. (2011), relataram coeficientes de herdabilidade entre 0,95 e 0,98 para as características de idade ao primeiro parto, produtividade acumulada, stayability e prenhez de novilha aos 30 meses de idade na raça Nelore e correlações genéticas entre 0,29 e 0,46 para as características de idade ao primeiro parto, produtividade acumulada, stayability e probabilidade de prenhez de novilhas aos 30 meses de idade. Foram reportados incrementos de 56,0\% para idade ao primeiro parto, $36,0 \%$ para produtividade acumulada, $62,0 \%$ para stayability e 19,0\% para probabilidade de prenhez de novilhas aos 30 meses de idade nas acurácias dos machos jovens, candidatos ao teste de progênie.

No Brasil existem três painéis comerciais de marcadores moleculares que estão disponíveis para utilização na raça Nelore. Esses painéis são formados por centenas de marcadores e são comercializados por três empresas. As informações dos marcadores genéticos e os respectivos efeitos de substituição alélica não são divulgados, porém duas delas divulgam informações adicionais como correlação genética entre os valores genéticos moleculares e os valores genéticos reais das populações de referência e os valores genéticos moleculares máximo e mínimo para cada característica (IGENITY/NEOGEN CORPORATION, 2012; PFIZER ANIMAL GENETICS, 2011).

\footnotetext{
* Informação fornecida por Prof. Dr. José Bento Sterman Ferraz no Encontro técnico CFM, em São José do Rio Preto, em 10 de agosto de 2011.
} 


\subsection{Ultrassonografia na avaliação de precocidade de acabamento e crescimento de bovinos de corte}

A produção de carcaças de peso adequado e com quantidade mínima de gordura subcutânea, de forma a garantir a qualidade da carne durante o processo de resfriamento, é um dos principais pontos de interesse para a cadeia produtiva da carne. A determinação do ponto ideal de abate dos animais de diferentes grupos genéticos em cada um dos diversos sistemas de produção disponíveis torna-se ferramenta importante para determinar a qualidade do produto (SUGUISAWA, 2002).

Metodologias utilizando medidas realizadas diretamente na carcaça apresentam uma boa correlação com a composição da mesma, entretanto, exigem o abate do animal, demandam muito tempo e são de alto custo (HEDRICK, 1983; SILVA, 2002).

A avaliação de carcaça por ultrassonografia in vivo possibilita determinar o grau de terminação e de desenvolvimento muscular dos animais, sem a necessidade de abatê-los (SILVA, 2002). A mensuração de características como área de olho de lombo (AOL), espessura de gordura subcutânea (EGS) e espessura de gordura na picanha (EGP) através da ultrassonografia pode fornecer informações importantes da composição de carcaça dos animais, para o desenvolvimento de modelos de predição da curva de crescimento e para a incorporação em programas de seleção animal (BERGEN et al, 1996).

A medida da $A O L$ pelo método de ultrassom é realizada entre a $12^{\underline{a}} \mathrm{e}$ 13aㅡ costelas, pois é de fácil localização e diversos estudos relatam correlação positiva entre AOL em relação ao peso vivo, musculosidade, quantidade e porcentagem de cortes comerciais (HEDRICK, 1983; LUCHIARI FILHO, 2000; SILVA et al, 2003; SUGUISAWA, 2002).

A deposição de gordura na carcaça é amplamente variável ao longo do processo de crescimento do animal. À medida que a gordura corporal aumenta, ocorre diminuição da porcentagem de carne magra (BERG; BUTTERFIELD, 1979). A deposição de gordura é importante tanto para o produtor quanto para a indústria frigorífica. Do ponto de vista da indústria frigorífica, um nível mínino de gordura de cobertura é importante para proteção da carcaça durante o 
resfriamento evitando a desvalorização do produto (LUCHIARI FILHO, 2000). Do ponto de vista do produtor, diminuindo os custos de alimentação e determinando o grau de acabamento de carcaça para o abate (SUGUISAWA, 2002).

A EGS, medida a $3 / 4$ da borda medial sobre o músculo Longissimus dorsi é um eficiente indicador de acabamento de carcaça, sendo inversamente correlacionada à porcentagem de porção de cortes comerciais (HEDRICK, 1983; SILVA et al, 2003; SILVA et al, 2004; SUGUISAWA, 2002). A medida da espessura de gordura na picanha (EGP), que é espessura da gordura subcutânea sobre o terço superior do músculo Biceps femoris é um bom indicador da gordura total da carcaça, explicando uma grande proporção da variação na porcentagem de gordura na carcaça (BAUD, 1998; WILLIAMS, 1992).

Em programas de melhoramento genético, a técnica de ultrassonografia é um importante instrumento por apresentar vantagens na seleção de animais para características de precocidade de acabamento e crescimento, pois estão correlacionadas com o rendimento de cortes cárneos e precocidade de acabamento em carcaças de bovinos de corte (SUGUISAWA, 2002). Em uma revisão de dez estudos com animais de diversas raças taurinas foi descrito que as características de área de olho de lombo e espessura de gordura subcutânea da carcaça apresentaram coeficientes de herdabilidade de 0,32 e 0,28, respectivamente (HERRING; KEMP, 2001).

$\mathrm{Na}$ raça Nelore, um dos primeiros trabalhos de estimação de parâmetros genéticos de características de carcaça medidas por ultrassom, avaliou dois rebanhos e encontrou coeficientes de herdabilidade de 0,19 (Agro-pecuária CFM) e 0,41 (Manah Agropastoril) para AOL e 0,05 (Agropecuária CFM) e 0,19 (Manah Agropastoril) para EGS (FIGUEIREDO, 2001).

ARAÚJO (2003) relatou coeficientes de herdabilidade de 0,29 para AOL, 0,44 para EGS e 0,62 para EGP em avaliações de machos e fêmeas da raça Nelore. Em estudo envolvendo animais originários de 10 fazendas de 06 estados diferentes do Brasil, utilizando mensurações de ultrassom de machos e fêmeas, as estimativas de herdabilidade relatadas foram de 0,29 para AOL, 0,50 para EGS e 0,39 para EGP (YOKOO et al., 2010).

Cucco (2010) estudando os componentes de variância e parâmetros 
genéticos de animais da raça Nelore utilizando três modelos diferentes relatou coeficientes de herdabilidade variando de 0,31 a 0,39 para AOL, 0,21 a 0,22 para EGS e 0,41 a 0,47 para EGP. 


\section{HIPÓTESES}

1. A inclusão dos valores genéticos moleculares como característica correlacionada nas avaliações genéticas, em conjunto com as informações fenotípicas e de pedigree, aumenta a acurácia das estimativas dos valores genéticos para características de carcaça em análise bi-característica.

2. A ordenação dos animais, segundo os valores genéticos preditos, é modificada com a inclusão dos valores genéticos moleculares na avaliação genética de características de carcaça.

3. O ganho genético anual esperado para características de carcaça é aumentado com a inclusão dos valores genéticos moleculares na avaliação genética. 


\section{OBJETIVOS}

\subsection{Objetivo geral}

Avaliar o efeito da inclusão dos valores genéticos moleculares nos modelos de avaliação genética de características de carcaça medidas por ultrassom em bovinos da raça Nelore.

\subsection{Objetivos específicos}

- Estudar o efeito da inclusão dos valores genéticos moleculares como característica correlacionada no modelo de estimação de parâmetros genéticos, assim como suas correlações genéticas e proporção da variância genética aditiva explicada pelos marcadores genéticos;

- Avaliar o efeito nas acurácias das estimativas de valores genéticos preditos obtidos pelo modelo bi-característica, comparando-as com as obtidas pelo modelo uni-caraterística.

- Comparar a classificação dos animais e avaliar os conflitos de seleção dos valores genéticos preditos pelos modelos uni e bi-característica.

- Avaliar o efeito da seleção assistida por marcadores genéticos no ganho genético anual esperado, comparando-o com o ganho genético anual esperado pela seleção realizada pelos parâmetros obtidos na análise uni-característica. 


\section{MATERIAL E MÉTODOS}

\subsection{Animais avaliados}

O presente estudo foi desenvolvido utilizando o banco de dados fenotípicos e moleculares de bovinos da raça Nelore pertencentes à Agropecuária CFM Ltda. Esses dados estão armazenados e foram analisados no Laboratório de Melhoramento Genético "Dr. Gordon Dickerson" do Grupo de Melhoramento Animal e Biotecnologia (GMAB), pertencente ao Departamento de Ciências Básicas da Faculdade de Zootecnia e Engenharia de Alimentos da Universidade de São Paulo.

Esses animais foram criados em sistema extensivo em diversas fazendas do grupo nos estados de São Paulo e Mato Grosso do Sul. Os pastos dessas fazendas são formados predominantemente pelas gramíneas do gênero Brachiaria ssp. e Panicum spp., sendo as mesmas a principal fonte de alimento dos animais, além de terem sido suplementados com sal mineral. Os animais foram mantidos nessas fazendas e com esse manejo até aproximadamente 20 meses de idade. Após esse período, os animais com melhores avaliações genéticas, foram levados para a Fazenda São Francisco, localizada no município de Magda, no estado de São Paulo (2038'38"S 50¹3'34"W, com altitude de 526 metros em relação ao nível do mar).

Os animais iniciaram o período de confinamento por volta dos 22 meses de idade e foram mantidos nesse regime por 90 a 150 dias, dependendo do ano, mercado e estágio de terminação. $O$ volumoso da dieta era baseado em silagem de milho e o concentrado em farelo de soja, milho em grão e núcleo mineral. A dieta foi formulada para promover ganhos de peso médio diário de aproximadamente $1.100 \mathrm{~g} /$ dia por animal.

As análises realizadas utilizaram a genealogia referente aos animais genotipados e todos os seus parentes, resultando em uma matriz de parentesco com 39.687 animais. 


\subsection{Metodologia de coleta de dados de carcaça por ultrassom}

Foram utilizadas mensurações 9.749 machos inteiros da raça Nelore de aproximadamente 18 meses de idade, nascidos entre 1997 e 2009. As mensurações por ultrassonografia das características de carcaça foram realizadas após a entrada dos animais em confinamento, porém devido às necessidades de manejo 1.393 animais foram mensurados antes da entrada no confinamento, entretanto, esses animais faziam parte dos mesmos grupos de contemporâneos de confinamento. Os grupos de contemporâneos dos animais confinados continham em média 100 animais.

As imagens de ultrassom foram obtidas através de dois equipamentos de ultrassom. Foi utilizado um equipamento da marca ALOKA, modelo SSD500V e um equipamento da marca Pie Medical, modelo Pie Medical Vet 200 , com transdutor linear de $3,5 \mathrm{MHz}$ de freqüência e $172 \mathrm{~mm}$ de comprimento. Foi utilizada uma guia acústica de silicone acoplada para melhor adaptação à anatomia do corpo do animal nas imagens captadas sobre o lombo.

Após a imobilização do animal em um tronco de contenção, o espaço entre a $12^{\mathrm{a}}$ e $13^{\mathrm{a}}$ costela era localizado, através de palpação. Sobre o local da medida foi utilizado óleo vegetal com objetivo de atuar como acoplante acústico. Então era realizada a obtenção das imagens de área de olho de lombo (AOL) e espessura de gordura subcutânea (EGS) com o transdutor localizado transversalmente ao animal no espaço entre a $12^{\mathrm{a}}$ e $13^{\mathrm{a}}$ costelas do animal sobre o músculo Longissimus dorsi (Figura1).

Para a colheita da imagem de espessura de gordura na picanha (EGP), colocou-se o transdutor, sem a guia acústica, sobre o músculo Bíceps femoris e Gluteus medius, em linha reta entre os ossos íleo e o ísquio, para a determinação da espessura de gordura (Figura 2).

As imagens obtidas foram gravadas em microcomputador portátil acoplado ao aparelho de ultrassom e posteriormente, foram analisados através de programa computacional específico para esta finalidade desenvolvido no GMAB. 


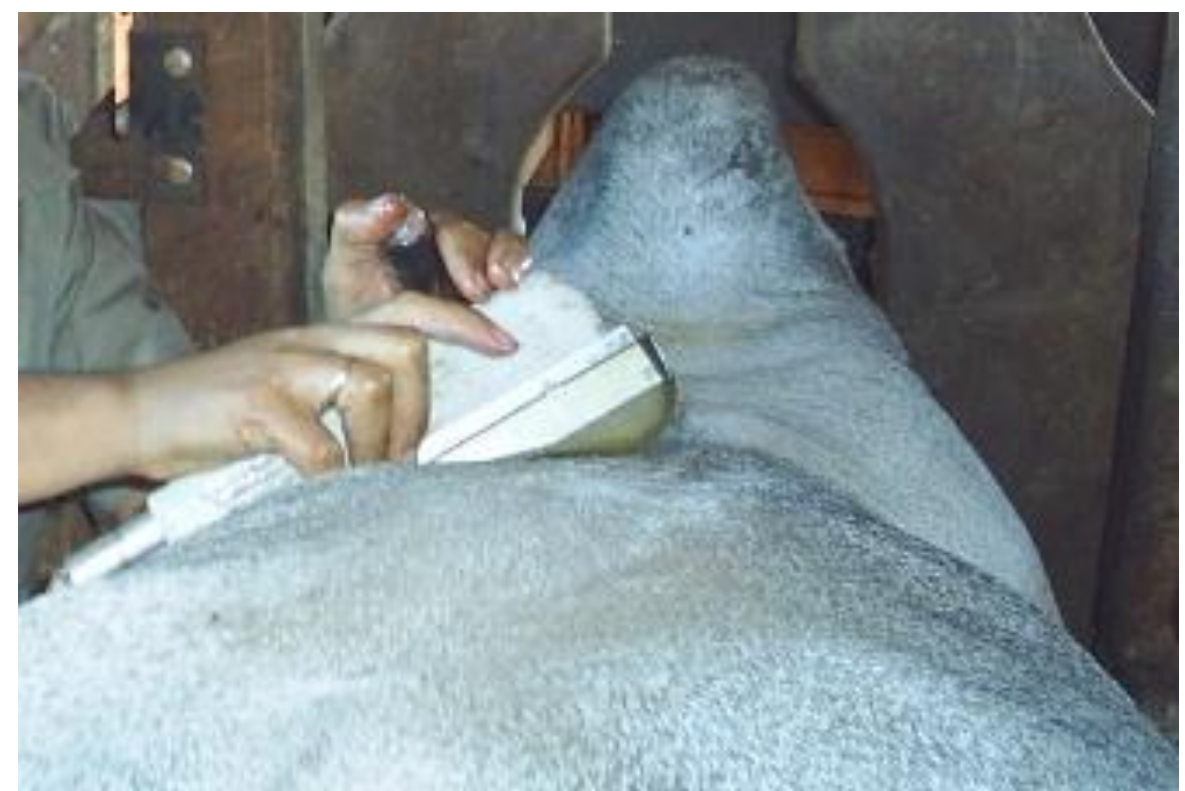

Figura 1 - Obtenção das imagens de área de olho de lombo (AOL) e espessura de gordura subcutânea (EGS)

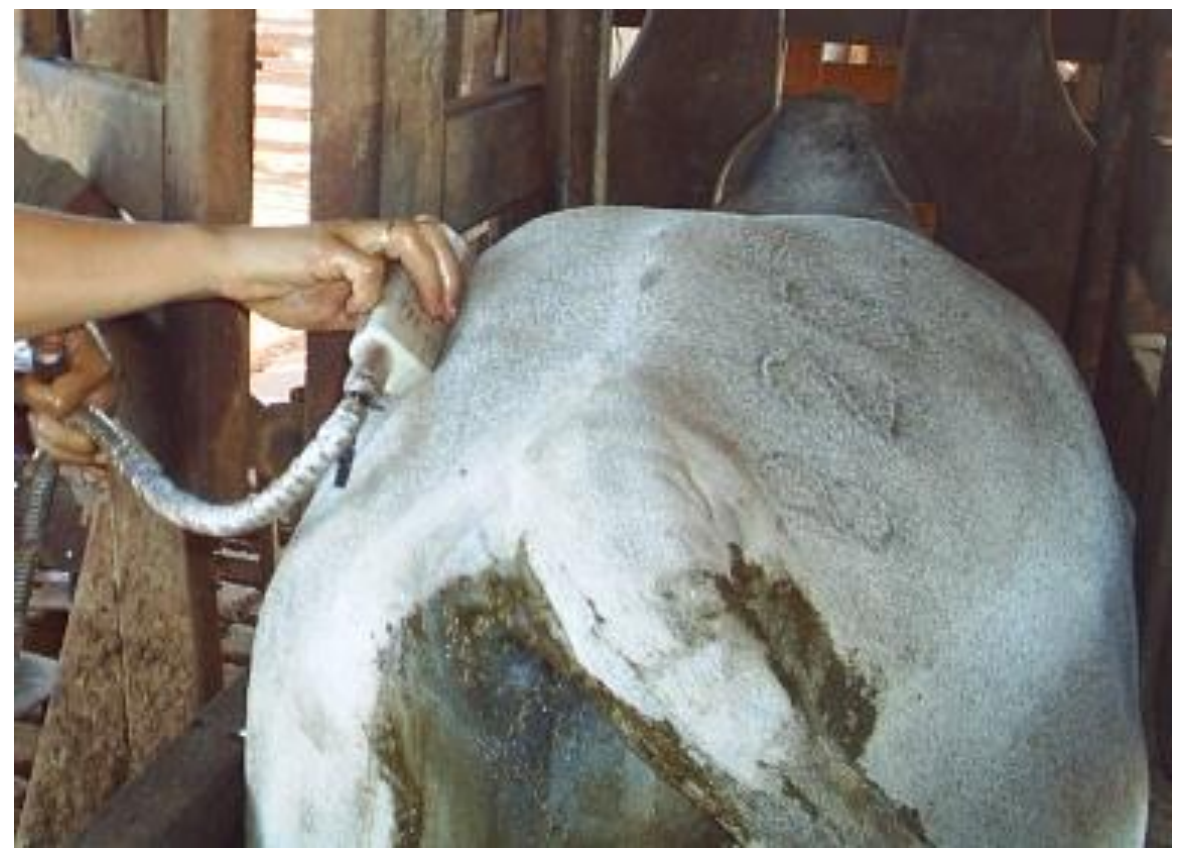

Figura 2 - Obtenção das imagens de espessura de gordura na picanha (EGP) 


\subsection{Coleta de amostras biológicas, extração de DNA, genotipagem e determinação dos valores genéticos moleculares (Perfil IGENITY® Nelore V3)}

Foram coletados aproximadamente 30 pêlos da vassoura do rabo de 3.033 animais, de forma que os folículos pilosos ficassem conservados na extremidade dos pêlos. Após a coleta, os pêlos foram armazenados em cartões com película adesiva para que ficassem protegidos durante o transporte até 0 laboratório.

Esses cartões foram enviados ao laboratório Deoxi em Araçatuba para a extração de DNA, onde se retirou de 3 a 5 folículos pilosos com o auxílio de um punch e através do método de extração e precipitação de $\mathrm{NaCl}$, descrito por Olerup e Zetterquist (1992), foi realizada a extração de DNA.

O DNA extraído foi enviado aos Estados Unidos da América para a realização da genotipagem das amostras pelos laboratórios licenciados pelo IGENITY®, que era uma unidade de negócios da Merial Saúde Animal Ltda. até maio de 2012. Atualmente a detentora dos painéis de marcadores genéticos IGENITY® é a empresa americana Neogen Corporation.

A caracterização e determinação dos genótipos para os marcadores SNP foi realizada por meio de PCR em Tempo Real utilizando o equipamento Sequenom iPlexTM Mass Spectrometry Array.

A partir dos genótipos dos animais, os valores genéticos moleculares foram calculados através do programa IGENITY GENOMICS, desenvolvido pela Merial Saúde Animal Ltda. e licenciado pela Neogen Corporation. O valor genético molecular (VGM) é a somatória dos efeitos de substituição alélica de cada marcador genético associado a uma determinada característica, ponderado pelos respectivos números de alelos favoráveis de cada marcador. O software IGENITY GENOMICS contém os efeitos de substituição alélica dos marcadores genéticos do tipo SNP para cada característica baseados nos trabalhos de pesquisa e de validação de marcadores genéticos em populações de referência da raça Nelore. Os efeitos de substituição alélica dos SNPs foram estimados pelo método Bayes $\mathrm{C} \pi \mathrm{C}$, em que a seleção dos SNPs é feita por Bayes $C \pi$ e a predição dos efeitos e validação cruzada é feita por Bayes $C$ 
(GIANOLA et al, 2009; HABIER et al, 2011). Os valores genéticos moleculares utilizados no presente trabalho foram estimados a partir dos efeitos de substituição alélica do Perfil IGENITY® Nelore V3, desenvolvido para a raça Nelore e comercializado por IGENITY/Neogen Corporation.

Foram utilizados os valores genéticos moleculares para as seguintes características:

- Valores genéticos moleculares de área de olho de lombo (VGM $\mathrm{VML}_{\mathrm{AL}}$ );

- Valores genéticos moleculares de espessura de gordura subcutânea (VGM $\mathrm{EGS}_{\text {); }}$

- Valores genéticos moleculares de espessura de gordura na picanha (VGMEGP)

\subsection{Análises Estatísticas}

\subsubsection{Estatística Descritiva}

As estatísticas descritivas das informações fenotípicas e dos valores genéticos moleculares foram calculadas pelo programa Statistical Analysis System, versão 9.1.3 (SAS INSTITUTE INC, 2004), utilizando-se os procedimentos PROC UNIVARIATE e PROC MEANS.

\subsubsection{Estimação de Parâmetros Genéticos e Componentes de Variância}

\subsection{Definição dos Efeitos Fixos}

Para os modelos uni-característica e bi-característica das mensurações de ultrassom, o grupo de contemporâneos aos 18 meses (GC18) foi considerado como efeito fixo classificatório no modelo, e como efeitos fixos contínuos (covariáveis) foram considerados a idade do animal e os dias de confinamento no dia da mensuração de ultrassom.

Para os modelos dos valores genéticos moleculares não foi utilizado nenhum efeito fixo, pois teoricamente, essas variáveis são formadas apenas 
por componentes de variância genética aditiva, isto é, não contém componentes de variância ambiental.

\subsection{Formação dos grupos de contemporâneos aos 18 meses (GC18)}

Os grupos de contemporâneos aos 18 meses foram formados com intuito de agrupar os animais que foram submetidos às condições de desenvolvimento semelhantes. Na formação do GC18 foram consideradas as variáveis fazenda, safra, ano de nascimento, estação de nascimento, sexo e lote de manejo aos 18 meses.

A verificação da consistência dos dados foi realizada para cada uma das características fenotípicas analisadas utilizando-se o programa Statistical Analysis System, versão 9.1.3 (SAS INSTITUTE INC, 2004). Animais com medidas fenotípicas de três desvios-padrão acima ou abaixo da média do seu grupo de contemporâneos (GC18) foram excluídos do banco de dados analisado. Adicionalmente foram desconsideradas as medidas fenotípicas de animais pertencentes a GC18 que continham apenas animais filhos de um mesmo touro e GC18 com menos de 03 animais.

\subsection{Efeitos Aleatórios}

Para os modelos uni-característica e bi-característica das mensurações de ultrassom foi considerado como efeito aleatório não correlacionado no modelo, o grupo de manejo a desmama (GMANDES). Segundo Pedrosa (2011), a inclusão do GMANDES como efeito aleatório não correlacionado favorece o aumento da quantidade de animais por grupo de contemporâneos (GC), evitando a formação de GC com pouca variabilidade e, consequentemente, possíveis eliminações de animais importantes nas avaliações. 


\subsection{Modelos}

Para a estimação dos componentes de variância e parâmetros genéticos foi utilizada a metodologia de modelos mistos sob modelo animal (HENDERSON, 1975) por meio do programa MTDFREML (BOLDMAN et al, 1995).

O MTDFREML utiliza o algoritmo simplex para calcular a variância dos valores do logaritmo da função de verossimilhança em cada ciclo de iteração. Como critério de convergência utilizou-se a variância dos valores do simplex inferiores a $10^{-6}$ na análise prévia. O programa foi reiniciado após cada convergência e utilizou-se as estimativas obtidas anteriormente como valores iniciais e a variância do simplex inferior a $10^{-9}$.

Para avaliar o efeito da incorporação dos valores genéticos moleculares no modelo matemático para estimação dos parâmetros genéticos das características estudadas foram realizadas uma análise uni-característica e uma análise bi-característica para cada característica avaliada. A análise unicaracterística (UNI) considera o fenótipo do animal para a característica como fonte de informação para a estimação de parâmetros genéticos, valores genéticos preditos (VG) e acurácias. A análise bi-característica (BI) considera o fenótipo do animal e o valor genético molecular (VGM) para a característica como fonte de informação para a estimação de parâmetros genéticos, valores genéticos preditos (VG) e acurácias (KACHMAN, 2008). As descrições dos modelos uni-característica (UNI) e bi-característica (BI) estão apresentadas abaixo:

\section{Modelo uni-característica}

O modelo genético utilizado nas análises uni-característica (UNI), na sua forma matricial, pode ser representado abaixo:

$y=\mathrm{X} \beta+\mathrm{Z} a+\mathrm{W} c+e$, em que:

$y$ é o vetor das variáveis dependentes ou observações;

$\beta$ é o vetor dos efeitos fixos; 
a é o vetor dos efeitos aleatórios de valor genético aditivo do animal;

$c$ é o vetor dos efeitos aleatórios não correlacionados;

$e$ é o vetor dos efeitos aleatórios residuais;

$X, Z$ e W são as matrizes de incidência relacionando as variáveis dependentes $(y)$ aos seus respectivos efeitos fixos $(\beta)$, genético aditivo do animal (a) e de efeitos aleatórios não correlacionados $(c)$, respectivamente.

\section{Modelos bi-característica}

Nas análises bi-característica, os valores genéticos moleculares e os fenótipos são considerados como sendo duas características correlacionadas. O modelo genético utilizado nas análises bi-característica, na sua forma matricial, pode ser representado abaixo:

$$
\left[\begin{array}{l}
y_{1} \\
y_{2}
\end{array}\right]=\left[\begin{array}{cc}
X_{1} & 0 \\
0 & X_{2}
\end{array}\right]\left[\begin{array}{l}
\beta_{1} \\
\beta_{2}
\end{array}\right]+\left[\begin{array}{cc}
Z_{1} & 0 \\
0 & Z_{2}
\end{array}\right]\left[\begin{array}{l}
a_{1} \\
a_{2}
\end{array}\right]+\left[\begin{array}{cc}
W_{1} & 0 \\
0 & W_{2}
\end{array}\right]\left[\begin{array}{l}
c_{1} \\
c_{2}
\end{array}\right]+\left[\begin{array}{l}
e_{1} \\
e_{2}
\end{array}\right],
$$

em que:

$y_{1}$ é o vetor das variáveis da característica 1 ;

$y_{2}$ é o vetor das variáveis do valor genético molecular da característica 1;

$\beta_{1}$ é o vetor dos efeitos fixos relacionados a característica 1;

$\beta_{2}$ é o vetor dos efeitos fixos relacionados ao valor genético molecular da característica 1;

$a_{1}$ é o vetor dos efeitos aleatórios de valor genético aditivo do animal para a característica 1;

$a_{2}$ é o vetor dos efeitos aleatórios de valor genético aditivo do animal para o valor genético molecular da característica 1 ;

$c_{1}$ é o vetor dos efeitos aleatórios não correlacionados para a característica 1;

$c_{2}$ é o vetor dos efeitos aleatórios não correlacionados para o valor genético molecular da característica 1 ;

$e_{1}$ é o vetor dos efeitos aleatórios residuais para a característica 1 ;

$e_{2}$ é o vetor dos efeitos aleatórios residuais para o valor genético molecular da característica 1 ;

$X_{1}, X_{2}, Z_{1}, Z_{2}, W_{1}$ e $W_{2}$ são as matrizes de incidência relacionando as variáveis 
dependentes $(y)$ aos seus respectivos efeitos fixos $(\beta)$, genético aditivo do animal (a) e de efeitos aleatórios não correlacionados (c) para a característica 1 ou valor genético molecular da característica 1, respectivamente.

Conforme proposto por Kachman (2008), para os valores genéticos moleculares (VGM), os vetores de efeitos fixos e efeitos aleatórios não correlacionados foram considerados como valores basais, pois os mesmos são baseados nos efeitos de substituição alélica dos marcadores genéticos e é esperado que a sua variância residual seja relativamente muito menor que a sua variância genética aditiva.

A proporção da variância genética aditiva explicada pelos valores genéticos moleculares foi obtida através da correlação genética aditiva das análises bi-característica elevada ao quadrado conforme proposto por Thallman et al. (2009).

\subsubsection{Análise dos valores genéticos preditos (VG) e das acurácias de predição $\left(r_{T, 1}\right)$}

As estatísticas descritivas dos valores genéticos preditos (VG) e das respectivas acurácias $\left(r_{T, l}\right)$ foram calculadas pelo programa $S A S$ versão 9.1.3 (SAS INSTITUTE INC, 2004), utilizando-se o procedimento PROC MEANS.

Os valores genéticos preditos obtidos pelas análises uni-característica e bi-característica foram analisados agrupando os animais que tinham VGM para a característica (animais genotipados) e os animais que não tinham VGM para a característica (animais não genotipados), calculando as médias, desviospadrão, valores máximos e valores mínimos.

As acurácias $\left(r_{T, 1}\right)$ das estimativas dos valores genéticos preditos foram obtidas por meio da seguinte equação:

$$
r_{T, I}=\sqrt{1-\frac{P E V}{\widehat{\sigma}_{a}^{2}}}, \text { em que: }
$$


$\mathrm{r}_{\mathrm{T}, \mathrm{l}}$ é a acurácia das estimativas dos valores genéticos preditos;

PEV é a variância do erro de predição;

$\widehat{\sigma}_{a}^{2}$ é a variância genética aditiva.

Foram realizadas análises por faixas de acurácia, onde as acurácias dos animais foram agrupadas de acordo a análise uni-característica, ou seja, as acurácias obtidas no cenário em que os VGM não são incluídos na avaliação genética. Dessa forma, foi possível verificar o efeito dos VGMs como fonte de informação adicional na média das acurácias. Os animais foram agrupados da seguinte forma:

- acurácia menor ou igual que 0,10;

- acurácia maior que 0,10 e menor ou igual a 0,30;

- acurácia maior que 0,30 e menor ou igual a 0,50;

- acurácia maior que 0,50 e menor ou igual a 0,70;

- acurácia maior que 0,70.

É comum em rebanhos da raça Nelore, a pressão de seleção nos machos ser maior do que nas fêmeas. Por isso, foi realizada a análise do efeito da inclusão dos VGMs na avaliação genética dos machos aptos a serem utilizados na estação de monta de acordo com as informações do banco de dados analisado. As acurácias desses machos foram analisadas com todos os indivíduos que atendiam os critérios citados acima (Machos) e, posteriormente, divididos em 02 grupos por categorias:

- Touros: Touros com 1 ou mais progênies com fenótipo no banco de dados analisado;

- Machos Jovens (CEIP): Machos jovens candidatos à certificação CEIP, onde apenas os $20 \%$ melhores de todo o rebanho são selecionados para se tornarem touros. A certificação CEIP é obtida por animais que participam de programas de melhoramento genético atestados pelo governo, onde apenas entre $20 \%$ e $30 \%$ dos melhores animais avaliados recebem esta certificação e podem ser comercializados com alguns benefícios fiscais. 


\subsubsection{Medidas de correlação e avaliação dos conflitos de seleção}

Foram estimados os coeficientes de correlação linear de Pearson e os coeficientes de correlação de postos de Spearman entre os VG UNI e VG BI por meio do procedimento PROC CORR do pacote estatístico programa Statistical Analysis System, versão 9.1.3 (SAS INSTITUTE INC, 2004).

A avaliação dos conflitos de seleção possibilita analisar as divergências na seleção dos animais em função do critério adotado, ou seja, possibilita verificar qual a proporção de animais que são selecionados por um critério e não pelo outro. Essa análise foi utilizada para verificar se a inclusão dos VGMs na avaliação genética interferiria na classificação dos animais. Os conflitos de seleção foram avaliados pelo cálculo da proporção de animais com classificação divergente ao serem selecionados os $20 \%$ melhores classificados pelos VG na população.

Os gráficos de dispersão entre as estimativas de $V G_{U N I}$ e $V G_{B I}$ foram feitos por meio do procedimento PROC GPLOT do pacote estatístico programa Statistical Analysis System, versão 9.1.3 (SAS INSTITUTE INC, 2004).

\subsubsection{Avaliação do ganho genético anual esperado}

Para avaliar o efeito da inclusão dos valores genéticos moleculares na avaliação genética sobre o ganho genético anual esperado, foi proposta uma situação hipotética, onde somente os $20 \%$ melhores machos foram selecionados para entrarem na estação de monta da fazenda, conforme o limite inferior da certificação CEIP.

A média das estimativas de acurácia dos machos utilizadas foram as mesmas apresentadas nas tabelas 10, 14 e 18 na categoria "Machos" incluindo os animais com VGM e os animais sem VGM (Geral), assim como as variâncias genética aditiva obtidas através das análises uni-característica e bicaracterística. 
Para os machos a intensidade de seleção utilizada foi de 1,4 (20\% melhores) e intervalo de gerações de 3,5 anos e para as fêmeas a intensidade de seleção foi de 0,8 (50\% melhores) e intervalo de gerações de 5 anos para as fêmeas. $O$ ganho genético anual. $O$ ganho genético anual esperado foi calculado pela seguinte equação (VAN DER WERF, 2006b):

$$
\Delta G / \text { ano }=\left[\frac{\left(i_{m} * r_{m}\right)+\left(i_{f} * r_{f}\right)}{\left(L_{m}+L_{f}\right)}\right] * \widehat{\sigma}_{a}, \text { em que: }
$$

$\Delta \mathrm{G} /$ ano é o ganho genético anual esperado;

$\mathrm{i}_{\mathrm{m}}$ é a intensidade de seleção dos machos;

if é a intensidade de seleção das fêmeas;

$r_{m}$ é a acurácia de seleção dos machos;

$r_{m}$ é a acurácia de seleção das fêmeas;

$L_{m}$ é o intervalo de gerações dos machos;

$L_{f}$ é o intervalo de gerações das fêmeas;

$\widehat{\sigma}_{a}$ é o desvio padrão genético aditivo. 


\section{RESULTADOS E DISCUSSÃo}

\subsection{Estatística Descritiva}

As estatísticas descritivas de todas as características avaliadas, idade do animal no dia da mensuração do ultrassom e dias de confinamento no dia da mensuração estão descritos na Tabela 1.

Tabela 1. Número de observações e estatísticas descritivas para idade no dia da mensuração do ultrassom (IDADE US), dias de confinamento no dia da mensuração (DIAS CONF), área de olho de lombo (AOL), espessura de gordura subcutânea (EGS) e espessura de gordura na picanha (EGP) medidas por ultrassom de animais da raça Nelore.

\begin{tabular}{cccccc}
\hline Característica & $\mathbf{N}$ & $\boldsymbol{\mu}$ & $\mathbf{D P}$ & $\mathbf{M I N}$ & MAX \\
\hline IDADE US, dias & 9.749 & 543,7 & 37,5 & 399 & 817 \\
DIAS CONF, dias & 9.749 & 42,8 & 44,4 & -14 & 127 \\
AOL, cm ${ }^{2}$ & 9.749 & 56,4 & 11,8 & 22,8 & 93,8 \\
EGS, mm & 9.653 & 2,36 & 1,68 & 0 & 9,4 \\
EGP, mm & 6.375 & 4,66 & 2,02 & 0,5 & 14,0 \\
\hline
\end{tabular}

$\mathrm{N}=$ número de observações; $\boldsymbol{\mu}=$ média; $\mathrm{DP}=$ desvio padrão; $\mathrm{CV}=$ coeficiente de variação (\%); $M I N=$ valor mínimo observado; $M A X=$ valor máximo observado.

As médias dos valores fenotípicos de características de carcaça mensuradas por ultrassom em animais da raça Nelore descritos em diversos trabalhos consultados variaram de 42,6 a $65,0 \mathrm{~cm}^{2}$ para $A O L, 1,30$ a 3,4 $\mathrm{mm}$ para EGS, 1,8 a 4,66 mm para EGP. Os valores das medidas descritivas encontradas para AOL, EGS e EGP estão próximos aos relatados nos trabalhos consultados, porém as médias são bem diferentes entre os trabalhos em Nelore, principalmente para EGS e EGP (FIGUEIREDO, 2001; ARAUJO, 2003; PRADO et al., 2004; SILVA et al., 2004; SOUZA et al., 2010; CUCCO, 2010; YOKOO et al., 2010). As diferentes médias encontradas se devem principalmente pelas diferentes condições ambientais aos quais os animais foram submetidos e, também pelas diferenças entre os rebanhos avaliados em cada estudo.

As estatísticas descritivas de todas as características avaliadas, idade do animal no dia da mensuração do ultrassom e dias de confinamento no dia 
da mensuração dos animais genotipados e não genotipados estão descritos na Tabela 2.

Tabela 2. Número de observações e estatísticas descritivas para idade no dia da mensuração do ultrassom (IDADE US), dias de confinamento no dia da mensuração (DIAS CONF), área de olho de lombo (AOL), espessura de gordura subcutânea (EGS) e espessura de gordura na picanha (EGP) de animais da raça Nelore, dividido em animais genotipados e não genotipados.

\begin{tabular}{ccccccc}
\hline Característica & & $\mathbf{N}$ & $\boldsymbol{\mu}$ & $\mathbf{D P}$ & $\mathbf{M I N}$ & MAX \\
\hline \multirow{2}{*}{ IDADE US, dias } & com VGM & 3.033 & 548,1 & 34,2 & 456 & 653 \\
& sem VGM & 6.716 & 543,3 & 37,8 & 399 & 817 \\
\hline \multirow{2}{*}{ DIAS CONF, dias } & com VGM & 3.033 & 62,1 & 25,6 & 0 & 127 \\
& sem VGM & 6.716 & 40,9 & 45,4 & -14 & 127 \\
\hline \multirow{2}{*}{ AOL, cm ${ }^{2}$} & com VGM & 3.033 & 64,2 & 7,8 & 32,8 & 85,9 \\
& sem VGM & 6.716 & 55,6 & 11,9 & 22,8 & 93,8 \\
\hline \multirow{2}{*}{ EGS, mm } & com VGM & 3.033 & 2,83 & 1,5 & 0 & 7,70 \\
& sem VGM & 6.620 & 2,31 & 1,69 & 0 & 9,4 \\
\hline \multirow{2}{*}{ EGP, $\mathbf{m m}$} & com VGM & 3.033 & 4,66 & 1,93 & 0,50 & 11,90 \\
& sem VGM & 3.342 & 4,65 & 2,03 & 0,50 & 14,00 \\
\hline
\end{tabular}

$\mathrm{N}$ = número de observações; $\mu$ = média; $\mathrm{DP}=$ desvio padrão; $\mathrm{CV}$ = coeficiente de variação (\%); MIN = valor mínimo observado; $M A X=$ valor máximo observado.

As estatísticas descritivas dos valores genéticos moleculares estão descritos na Tabela 3.

Tabela 3. Número de observações e estatísticas descritivas dos valores genéticos moleculares para área de olho de lombo (VGM $\mathrm{AOL}_{\mathrm{L}}$ ), espessura de

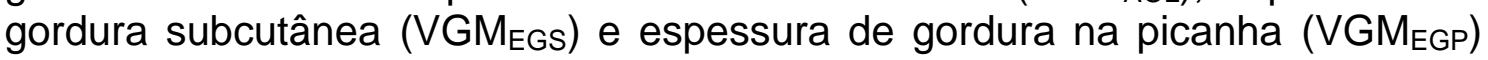
de animais genotipados da raça Nelore.

\begin{tabular}{cccccc}
\hline Característica & $\mathbf{N}$ & $\boldsymbol{\mu}$ & $\mathbf{D P}$ & $\mathbf{M I N}$ & $\mathbf{M A X}$ \\
\hline VGM $_{\text {AOL }}, \mathbf{c m}^{2}$ & 3.033 & 0,009 & 0,287 & $-1,003$ & 1,116 \\
VGM $_{\text {EGS }}, \mathbf{m m}$ & 3.033 & 0,012 & 0,058 & $-0,187$ & 0,265 \\
VGM $_{\mathrm{EGP}}, \mathbf{m m}$ & 3.033 & 0,043 & 0,192 & $-0,590$ & 0,863 \\
\hline
\end{tabular}

$\mathrm{N}=$ número de observações; $\mu=$ média; $\mathrm{DP}=$ desvio padrão; $\mathrm{MIN}=$ valor mínimo observado; MAX = valor máximo observado.

As médias dos valores genéticos moleculares ficaram bem próximas de zero, pois são estimados como desvios da média da população de validação. Não existe na literatura cientifica nenhum trabalho com referências dos valores genéticos moleculares do perfil IGENITY® Nelore V3 para podermos comparar com os valores encontrados nesse estudo. 
Nas figuras 3, 4 e 5 foram apresentados os histogramas e 0 comportamento das distribuições das características e dos valores genéticos moleculares analisados nesse estudo.

A maioria dos animais mensurados para EGS (em torno de $21 \%$ dos animais) tiveram medidas iguais a zero, pois não tinham deposição de gordura subcutânea sobre o lombo na data da realização das imagens de ultrassom. Os dados foram mantidos nas análises. 

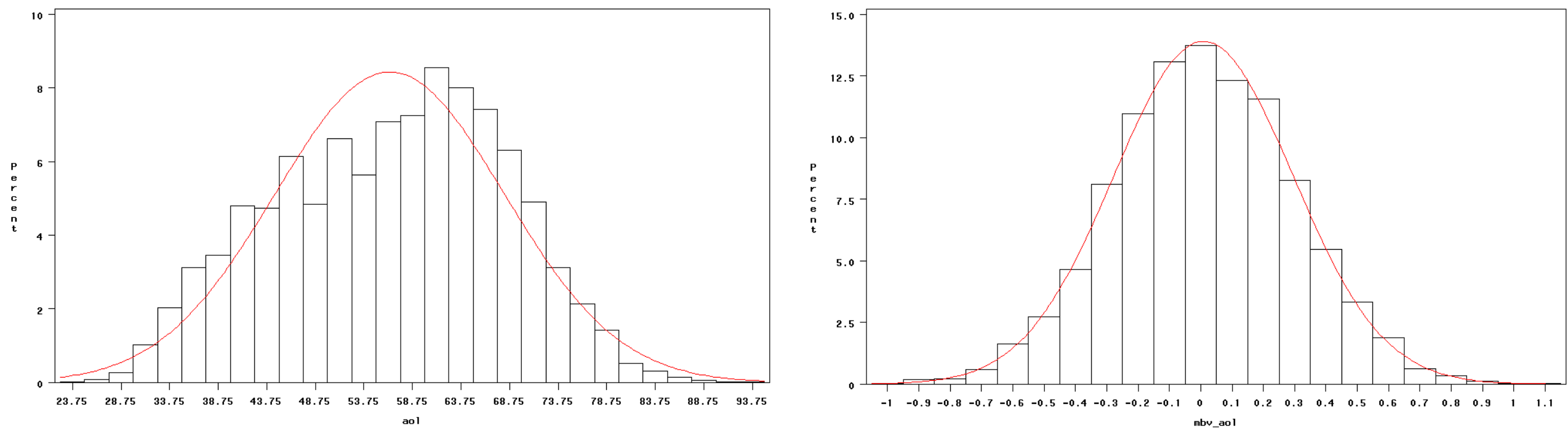

Figura 3. Histogramas de $A O L$ e VGM $\mathrm{AOL}_{\mathrm{A}}$ 

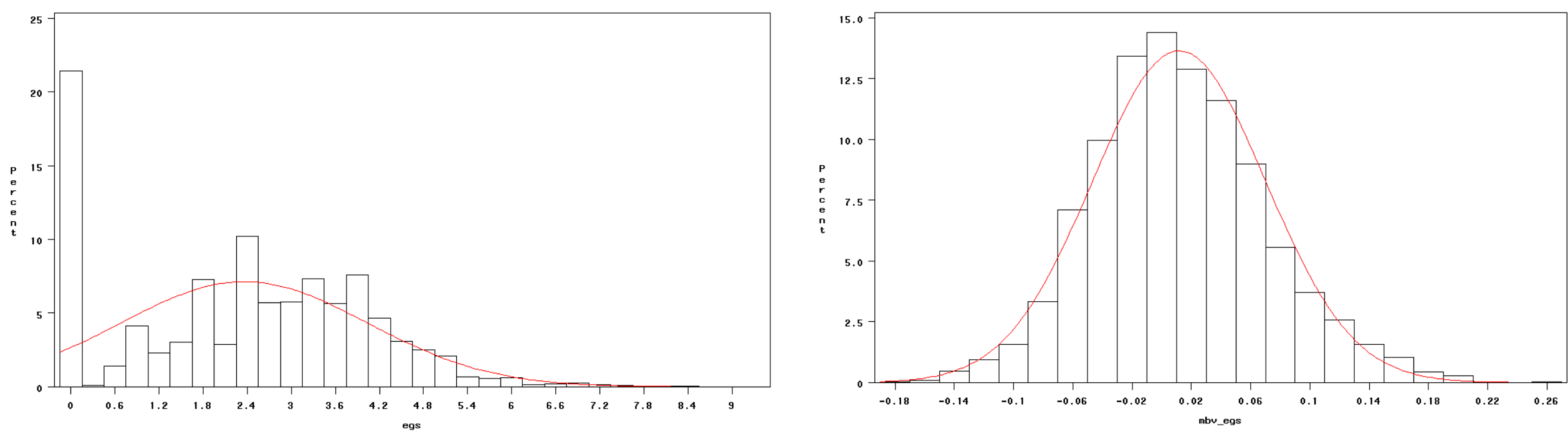

Figura 4. Histogramas de EGS e VGMEGS 

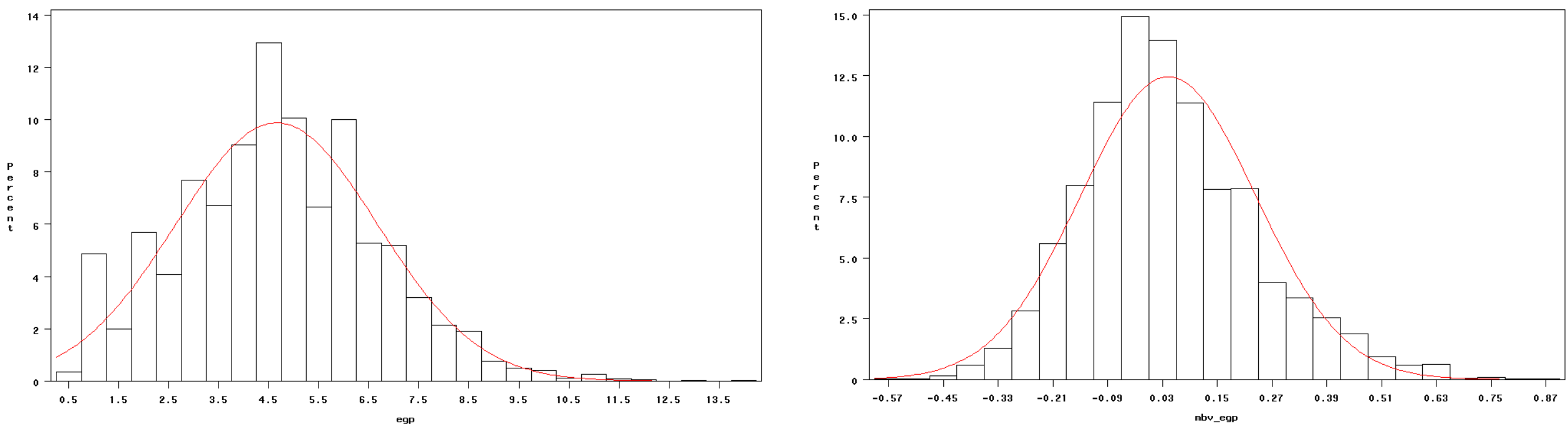

Figura 5. Histogramas de EGP e VGMEGP 


\subsection{Parâmetros genéticos e componentes de (co) variância para as características de carcaça}

\subsection{1 Área de olho de lombo (AOL)}

A Tabela 4 apresenta os componentes de variância e parâmetros genéticos para AOL para os dois modelos propostos.

As variâncias fenotípicas foram semelhantes nos dois modelos avaliados. Os coeficientes de herdabilidade também foram semelhantes para os dois modelos, sendo que, para o modelo UNI, a estimativa foi levemente maior quando comparado com a estimativa do modelo BI. Isso demonstra que a inclusão das informações moleculares não alterou a dinâmica da estimação dos parâmetros genéticos para AOL, pois os resultados são semelhantes entre o modelo com inclusão dos valores genéticos moleculares e a análise unicaracterística.

Na revisão realizada por Herring e Kemp (2001) foi observada média de coeficientes de herdabilidade de 0,32 para $A O L$, porém os diferentes trabalhos utilizaram modelos diferentes para estimação dos parâmetros e foi feita em sua grande maioria em raças taurinas. Outra revisão com 36 publicações consultadas, os autores relataram que a média de estimativas de herdabilidade para $A O L$ em animais de raças taurinas e seus cruzamentos era de 0,41 (UTRERA; VANVLECK, 2004).

Um dos primeiros trabalhos realizados estimando parâmetros genéticos para características de carcaça mensuradas por ultrassom na raça Nelore relatou coeficientes de herdabilidade de 0,19 e 0,41 para dois rebanhos distintos (FIGUEIREDO, 2001).

Araujo (2003) e Yokoo et al. (2010) relataram estimativas semelhantes para esse parâmetro na raça Nelore para a característica $A O L\left(h^{2}=0,29\right)$. Outro estudo com estimativas de parâmetros genéticos a partir de três modelos que consideravam diferentes efeitos, incluindo efeito genético materno, encontrou estimativas que variaram de 0,31 a 0,39 (CUCCO, 2010). 
Tabela 4. Componentes de variância, parâmetros genéticos e seus respectivos desvios padrão para área de olho de lombo para análise uni-característica (UNI) e bi-característica (BI).

\begin{tabular}{|c|c|c|c|}
\hline Modelo & UNI & \multicolumn{2}{|c|}{ BI } \\
\hline Componentes de variância & AOL & AOL & $\mathrm{VGM}_{\mathrm{AOL}}$ \\
\hline$\sigma_{a}^{2}$ & 10,70 & 9,74 & 0,062 \\
\hline$\sigma_{e}^{2}$ & 28,81 & 29,62 & 0,016 \\
\hline$\sigma_{f}^{2}$ & 40,68 & 40,51 & 0,078 \\
\hline$\sigma_{\mathrm{a} 1, \mathrm{a} 2}$ & - & \multicolumn{2}{|c|}{0,30} \\
\hline \multicolumn{4}{|l|}{ Parâmetros Genéticos } \\
\hline $\mathrm{h}^{2} \mathrm{a}$ & $\begin{array}{c}0,26 \\
(0,04)\end{array}$ & 0,24 & 0,80 \\
\hline $\mathbf{e}^{2}$ & $\begin{array}{c}0,71 \\
(0,04)\end{array}$ & 0,73 & 0,20 \\
\hline $\mathbf{r}_{\mathrm{a} 1, \mathrm{a} 2}$ & - & \multicolumn{2}{|c|}{0,39} \\
\hline
\end{tabular}

Os coeficientes de herdabilidade do presente estudo foram menores que os relatados nos trabalhos consultados, com exceção da herdabilidade encontrada para uma das populações estudadas por Figueiredo (2001). Apesar disso, elas estão bem próximas das estimativas relatadas na raça Nelore por Araujo (2003) e Yokoo et al (2010). Essas diferenças ocorrem por diversos fatores, mas os principais fatores de diferença nas estimativas podem ser atribuídas às diferenças das populações avaliadas e aos modelos aplicados nas análises.

A correlação genética dos valores genéticos moleculares e dos fenótipos é um parâmetro para calcular a variância genética explicada pelos painéis de marcadores moleculares (LANDE; THOMPSON, 1996; MEUWISSEN; GODDARD, 1996). No presente estudo foi verificado que a correlação genética de $A O L$ e VGM $\mathrm{AOL}_{\text {do }}$ modelo BI foi de 0,39. MacNeil et al. (2010) estudando o efeito da inclusão dos valores genéticos moleculares para marmoreio na estimação de parâmetros genéticos de marmoreio mensurado por ultrassom, encontraram correlação genética de 0,38 em animais da raça Angus. Outro estudo avaliou o efeito da inclusão de valores genéticos moleculares na 
avaliação genética de animais da raça Angus do Canadá e descreveram correlações genéticas de 0,61 para peso ao nascimento, 0,39 para peso a desmama, 0,14 para efeito materno de peso a desmama, 0,38 para peso aos 12 meses de idade, 0,57 para peso adulto e 0,54 para perímetro escrotal (TANG et al., 2011). Estudando o efeito da inclusão de valores genéticos moleculares na avaliação genética de animais da raça Nelore, Lôbo et al. (2011) relataram correlações genéticas entre 0,29 e 0,46 para as características de idade ao primeiro parto, produtividade acumulada, stayability e probabilidade de prenhez de novilhas aos 30 meses de idade.

A proporção da variância genética aditiva explicada pelo $\mathrm{VGM}_{\mathrm{AOL}}$ foi de aproximadamente 0,15 , ou seja, esse painel explica em torno de $15 \%$ da variância genética aditiva de AOL. Crews, Moore and Enns (2008) sugeriram que os painéis de marcadores moleculares para serem úteis precisariam explicar ao menos entre $10 \%$ a $15 \%$ da variância genética aditiva das características de interesse.

O coeficiente de herdabilidade do $\mathrm{VGM}_{\mathrm{AOL}}$ no modelo $\mathrm{BI}$ de 0,80 é um indicativo que estão sendo incluídos os efeitos genéticos aditivos dos SNPs. MacNeil et al. (2010) relataram estimativas de 0,98 para as estimativas obtidas a partir dos valores genéticos moleculares para marmoreio em animais da raça Angus, enquanto Tang et al. (2011) reportaram coeficientes de herdabilidade dos painéis de marcadores avaliados entre 0,84 e 0,92 para características de crescimento na raça Angus. Lôbo et al. (2011) apresentaram estimativas entre 0,95 e 0,98 para esse parâmetro para as características de idade ao primeiro parto, produtividade acumulada, stayability e prenhez de novilha aos 30 meses de idade na raça Nelore. O coeficiente de herdabilidade de $V_{G M} M_{A O L}$ é considerado alto para as características quantitativas comumente estudadas na raça Nelore, porém isso é esperado, já que os efeitos genéticos aditivos dos SNPs são considerados para se obter os valores genéticos moleculares de cada painel de marcadores. Isso é indica que a variância genética explicada pelos valores genéticos moleculares pode ser útil como fonte de informação adicional para a estimação dos valores genéticos. 


\subsubsection{Espessura de gordura subcutânea (EGS)}

A Tabela 5 apresenta os componentes de variância e parâmetros genéticos para EGS para os dois modelos propostos.

As variâncias fenotípicas foram semelhantes nos dois modelos avaliados. Os coeficientes de herdabilidade também foram semelhantes para os dois modelos, sendo que para o modelo $\mathrm{BI}$, o coeficiente de herdabilidade foi menor que no modelo UNI. A inclusão dos valores genéticos moleculares como fonte de informação para estimação dos componentes de variância teve muito pouca influência na alteração da proporção dos parâmetros genéticos para EGS, pois os resultados são semelhantes entre o modelo com a inclusão dos valores genéticos moleculares e a análise uni-característica.

Tabela 5. Componentes de variância, parâmetros genéticos e seus respectivos desvios padrão para espessura de gordura subcutânea para análise unicaracterística (UNI) e bi-característica (BI).

\begin{tabular}{|c|c|c|c|}
\hline Modelo & UNI & \multicolumn{2}{|c|}{ BI } \\
\hline Componentes de variância & EGS & EGS & $\mathrm{VGM}_{\mathrm{EGS}}$ \\
\hline$\overline{\sigma_{a}^{2}}$ & 0,27 & 0,23 & 0,002 \\
\hline$\sigma^{2}{ }_{e}$ & 0,90 & 0,93 & 0,001 \\
\hline$\sigma_{f}^{2}$ & 1,17 & 1,17 & 0,003 \\
\hline$\sigma_{\mathrm{a} 1, \mathrm{a} 2}$ & - & \multicolumn{2}{|c|}{0,008} \\
\hline \multicolumn{4}{|l|}{ Parâmetros Genéticos } \\
\hline $\mathbf{h}^{2}{ }_{a}$ & $\begin{array}{c}0,23 \\
(0,03)\end{array}$ & 0,19 & 0,78 \\
\hline$e^{2}$ & $\begin{array}{c}0,77 \\
(0,03)\end{array}$ & 0,80 & 0,22 \\
\hline $\mathbf{r}_{\mathrm{a1}, \mathrm{a} 2}$ & - & \multicolumn{2}{|c|}{0,37} \\
\hline
\end{tabular}

$\sigma^{2} \bar{a}=$ variância genética aditiva; $\sigma_{\mathrm{a} 1, \mathrm{a} 2}=$ covariância aditiva de EGS e VGM $\mathrm{EGS} \sigma^{2}{ }_{\mathrm{e}}=$ variância residual; $\sigma_{\mathrm{f}}{ }_{\mathrm{f}}=$ variância fenotípica; $\mathrm{h}_{\mathrm{a}}{ }_{\mathrm{a}}$ coeficiente de herdabilidade do efeito aditivo direto; $r_{a 1, a 2}=$ correlação genética entre efeito aditivo de EGS e VGM $\mathrm{EGS}_{\mathrm{ES}} \mathrm{e}^{2}=$ proporção da variância ambiental sobre a variância fenotípica.

Na revisão realizada por Herring e Kemp (2001) foi observada média de coeficientes de herdabilidade de 0,28 para EGS, porém os diferentes trabalhos 
utilizaram modelos diferentes para estimação dos parâmetros e foi feita em sua grande maioria em raças taurinas.

FIGUEIREDO (2001) relatou estimativas de 0,05 e 0,19 para dois rebanhos distintos da raça Nelore. Na revisão realizada por Utrera e Van Vleck (2004), os autores relataram média de estimativas de herdabilidade para EGS de 0,39 , porém a maioria dos trabalhos revisados foram realizados com dados de animais de raças taurinas e seus cruzamentos e criados em confinamentos.

Araujo (2003) relatou valor de coeficiente de herdabilidade para EGS na raça Nelore de 0,44. Yokoo et al. (2010) também estudando animais da raça Nelore relataram estimativas de 0,50 para EGS. Outro estudo com estimativas de parâmetros genéticos a partir de três modelos que consideravam diferentes efeitos, incluindo efeito genético materno, encontrou estimativas para esse parâmetro que variaram de 0,21 a 0,22 (CUCCO, 2010).

Os coeficientes de herdabilidade do presente estudo foram semelhantes aos apresentados para uma das populações estudadas por Figueiredo (2001) e por Cucco (2010). Essas diferenças ocorrem por diversos fatores, mas os principais fatores de diferença nas estimativas podem ser atribuídos às diferenças das populações avaliadas e aos modelos aplicados nas análises, além de fatores ambientais aos quais as populações foram submetidas.

No presente estudo foi verificado que a correlação genética de EGS e $V_{G M} M_{E G S}$ do modelo $B I$ foi de 0,37 . Em estudo semelhante com dados da raça Angus foi encontrada correlação genética de 0,38 dos valores genéticos moleculares e escore de marmoreio na estimação de parâmetros genéticos (MACNEIL et al., 2010).

O efeito da inclusão de valores genéticos moleculares na avaliação genética de animais da raça Angus do Canadá proporcionou correlações genéticas de 0,61 para peso ao nascimento, 0,39 para peso a desmama, 0,14 para efeito materno de peso a desmama, 0,38 para peso aos 12 meses de idade, 0,57 para peso adulto e 0,54 para perímetro escrotal (TANG et al., 2011). Lôbo et al. (2011) relataram correlações genéticas entre 0,29 e 0,46 para as características de idade ao primeiro parto, produtividade acumulada, stayability e prenhez de novilha aos 30 meses de idade quando os valores genéticos moleculares das respectivas características foram incluídas na avaliação genética de animais da raça Nelore. 
A proporção da variância genética aditiva explicada pelo VGM $\mathrm{EGS}_{\text {foi de }}$ aproximadamente 0,14 , ou seja, esse painel explica em torno de $14 \%$ da variância genética aditiva de EGS. Crews, Moore and Enns (2008) sugeriram que os painéis de marcadores moleculares para serem uteis precisariam explicar ao menos entre $10 \%$ a $15 \%$ da variância genética aditiva da características de interesse.

O coeficiente de herdabilidade do $V_{G M}$ EGs no modelo BI de 0,78 é um indicativo que estão sendo incluídos os efeitos genéticos aditivos dos SNPs. Isso indica que os efeitos genéticos aditivos dos SNPs foram considerados para se obter os valores genéticos moleculares de cada painel de marcadores, de tal forma que a variância genética explicada pelos valores genéticos moleculares de EGS sugere que os mesmos podem ser importante fonte de informação adicional para a estimação dos valores genéticos.

\subsubsection{Espessura de gordura na picanha (EGP)}

A Tabela 6 apresenta os componentes de variância e parâmetros genéticos para EGP para os dois modelos propostos.

As variâncias fenotípicas foram semelhantes nos dois modelos avaliados. Os coeficientes de herdabilidade de EGP foram maiores que os encontrados para EGS em ambos modelos. O modelo uni-característica apresentou estimativa de herdabilidade maior que o modelo bi-característica.

Em estudo realizado em animais das raças Angus e Hereford foram encontrados coeficientes de herdabilidade que variaram de 0,31 a 0,55 (REVERTER et al., 2000).

Araujo (2003) relatou estimativas de 0,62 para EGP na raça Nelore. Yokoo et al. (2010) também estudando animais da raça Nelore relataram coeficientes de herdabilidade de 0,39 para essa característica. Outro estudo de estimativas de parâmetros genéticos obtidas a partir de três modelos que consideravam diferentes efeitos, incluindo efeito genético materno, encontrou estimativas de herdabilidade que variaram de 0,41 a 0,47 (CUCCO, 2010). 
Tabela 6. Componentes de variância, parâmetros genéticos e seus respectivos desvios padrão para espessura de gordura na picanha para análise unicaracterística (UNI) e bi-característica (BI).

\begin{tabular}{c|c|ccc}
\hline \multicolumn{1}{c}{ Modelo } & \multicolumn{2}{c}{ UNI } & \multicolumn{2}{c}{ BI } \\
\hline Componentes de variância & \multicolumn{1}{c}{ EGP } & \multicolumn{1}{c}{ EGP } & VGM ${ }_{\text {EGP }}$ \\
\hline $\boldsymbol{\sigma}^{2}{ }_{\mathbf{a}}$ & 0,83 & 0,72 & 0,02 \\
$\boldsymbol{\sigma}^{2}{ }_{\mathbf{a}}$ & 1,64 & 1,74 & 0,007 \\
$\boldsymbol{\sigma}_{\mathrm{f}}$ & 2,49 & 2,47 & 0,027 \\
$\boldsymbol{\sigma}_{\mathbf{a} 1, \mathrm{a} 2}$ & - & \multicolumn{2}{c}{0,06} \\
\hline
\end{tabular}

\begin{tabular}{|c|c|c|c|}
\hline \multicolumn{4}{|c|}{ Parâmetros Genéticos } \\
\hline $\mathrm{h}_{\mathrm{a}}^{2}$ & $\begin{array}{c}0,34 \\
(0,05)\end{array}$ & $\overline{0,29}$ & 0,75 \\
\hline $\mathrm{e}^{2}$ & $\begin{array}{c}0,66 \\
(0,05)\end{array}$ & 0,70 & 0,25 \\
\hline$r_{\mathrm{a} 1, \mathrm{a} 2}$ & - & & \\
\hline
\end{tabular}

$\sigma^{2} \bar{a}=$ variância genética aditiva; $\sigma_{\mathrm{a} 1, \mathrm{a} 2}=$ covariância aditiva de EGP e VGM $\mathrm{EGP}_{\mathrm{EP}} \sigma_{\mathrm{e}}^{2}=$ variância residual; $\sigma_{\mathrm{f}}{ }^{2}=$ variância fenotípica; $\mathrm{h}_{\mathrm{a}}{ }_{\mathrm{a}}$ coeficiente de herdabilidade do efeito aditivo direto; $r_{\text {a1,a2 }}=$ correlação genética entre efeito aditivo de EGP e VGM $\mathrm{EGP}_{\mathrm{EP}} ; \mathrm{e}^{2}=$ proporção da variância ambiental sobre a variância fenotípica.

As estimativas de herdabilidade do presente estudo diferiram dos estudos consultados. A proporção da variância ambiental sobre a variância fenotípica nos dois modelos estudados foi bem superior às proporções apresentadas nos trabalhos consultados (ARAUJO, 2003; CUCCO, 2010; REVERTER et al., 2000; YOKOO et al., 2010), diminuindo assim a estimativa do coeficiente de herdabilidade.

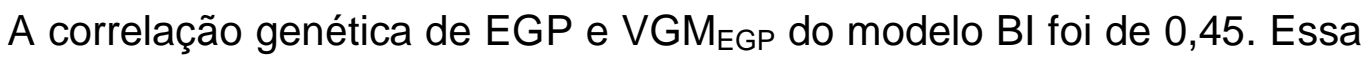
correlação é superior às encontradas no estudo realizado com EGS e AOL, sugerindo que os valores genéticos moleculares expliquem grande parte da variância genética da característica EGP. A proporção da variância genética aditiva explicada pelo $V G M_{E G S}$ foi de aproximadamente 0,20 , ou seja, esse painel explica em torno de $20 \%$ da variância genética aditiva de EGP para a população avaliada. Esse painel de marcadores explica acima dos 10\% a 15\% da variância genética aditiva sugerido por Crews, Moore and Enns (2008) para ser uma fonte de informação interessante para a inclusão na avaliação genética da característica. 
Diversos estudos com painéis de marcadores de baixa densidade têm demonstrado que a porção da variância genética aditiva explicada por esses painéis é pequena, porém podem ter um impacto positivo na inclusão das avaliações genéticas quantitativas (DEKKERS, 2004).

\subsection{Valores genéticos preditos e acurácias}

\subsection{1 Área de olho de lombo (AOL)}

As estatísticas descritivas dos valores genéticos preditos de área de olho de lombo para os dois modelos de análise estão descritos na Tabela 7.

Tabela 7. Número de observações e estatísticas descritivas dos valores genéticos preditos de área de olho de lombo (AOL) para análise unicaracterística (UNI) e bi-característica (BI).

\begin{tabular}{cccccc}
\hline Modelo & $\mathbf{N}$ & $\boldsymbol{\mu}$ & $\mathbf{D P}$ & MIN & MAX \\
\hline UNI & 37.720 & 0,296 & 1,231 & $-8,13$ & 7,97 \\
BI & 37.720 & 0,285 & 1,210 & $-7,56$ & 9,08
\end{tabular}

$\bar{N}=$ número de observações; $\boldsymbol{\mu}=$ média; $\mathrm{DP}=$ desvio padrão; $\mathrm{MIN}=$ valor mínimo observado; MAX = valor máximo observado.

A média dos valores genéticos preditos pela análise bi-característica foi menor que a média dos valores genéticos preditos pela análise unicaracterística para AOL. O desvio padrão dos valores genéticos preditos pela da análise bi-característica foi menor que da análise uni-característica.

Essas diferenças apresentadas demonstram que a inclusão dos valores genéticos moleculares na análise pode alterar a média dos valores genéticos preditos, porém os valores mínimos e máximos também são alterados e para a característica $\mathrm{AOL}$, esses valores foram maiores quando comparados com os valores obtidos a partir da análise uni-característica.

O número de observações e as estatísticas descritivas das acurácias de AOL para os dois modelos de análise estão descritos na Tabela 8. 
Tabela 8. Número de observações e estatísticas descritivas das acurácias de área de olho de lombo (AOL) para análise uni-característica (UNI) e bicaracterística $(\mathrm{BI})$.

\begin{tabular}{ccccccc}
\hline Modelo & & $\mathbf{N}$ & $\boldsymbol{\mu}$ & $\mathbf{D P}$ & MIN & MAX \\
\hline \multirow{3}{*}{ UNI } & Geral & 37.720 & 0,356 & 0,221 & 0 & 0,99 \\
& sem VGM $_{\text {AOL }}$ & 34.687 & 0,347 & 0,223 & 0 & 0,99 \\
& com VGM $_{\text {AOL }}$ & 3.033 & 0,460 & 0,150 & 0 & 0,96 \\
\hline \multirow{3}{*}{ BI } & Geral & 37.720 & 0,363 & 0,215 & 0,01 & 0,99 \\
& sem VGM & 34.687 & 0,347 & 0,216 & 0,01 & 0,99 \\
& com VGM & 3.033 & 0,545 & 0,098 & 0,34 & 0,96
\end{tabular}

$\mathrm{N}=$ número de observações; $\mu$ = média; $\mathrm{DP}=$ desvio padrão; $\mathrm{MIN}=$ valor mínimo observado; $\mathrm{MAX}=$ valor máximo observado.

Os resultados demonstrados na Tabela 8 indicam que na média as acurácias foram semelhantes para as duas análises quando são considerados todos os animais e somente os animais que não tinham VGM $\mathrm{AOL}_{\text {. Os animais }}$ que tinham a inclusão dos seus $V_{G M} M_{A O L}$ no modelo de análise apresentaram aumento considerável em suas acurácias. No caso do modelo $\mathrm{BI}$ o aumento comparado com o modelo UNI foi de aproximadamente 18,5\%. O incremento na acurácia causado pela inclusão dos valores genéticos moleculares na avaliação genética quantitativa está relacionado à proporção da variância genética aditiva explicada pelo painel de marcadores moleculares.

$\mathrm{Na}$ Tabela 9 estão descritas as médias das acurácias encontradas nos animais agrupados de acordo com as acurácias da análise UNI.

De acordo com a tabela 9, tanto os animais sem VGM AOL e com VGM que tinham acurácias menores ou iguais 0,10 na análise uni-característica apresentaram aumento na acurácia obtida a partir da análise bi-característica, porém os animais com $\mathrm{VGM}_{\mathrm{AOL}}$ tiveram um aumento bem superior aos

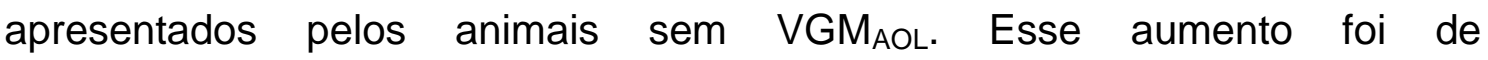
aproximadamente 0,30 na sua acurácia para animais com $V_{G M}$ e para os animais sem $V_{G M}$ AOL foi de aproximadamente 0,01 .

Os animais com $\mathrm{VGM}_{\mathrm{AOL}}$ tiveram aumentos consideráveis até o grupo com acurácia menor ou igual 0,50 que proporcionou um incremento de até 0,10 na acurácia. 
Tabela 9. Número de observações, médias e desvios-padrão (entre parênteses) das acurácias de área de olho de lombo (AOL) por faixas de acurácia estimadas de acordo com a análise uni-característica (UNI) e bicaracterística $(\mathrm{BI})$.

\begin{tabular}{|c|c|c|c|c|c|c|}
\hline \multirow{2}{*}{ Acurácias $\left(r_{T, 1}\right)$} & \multicolumn{3}{|c|}{ sem VGM $\mathrm{AOL}_{\mathrm{L}}$} & \multicolumn{3}{|c|}{ com VGM ${ }_{\mathrm{AOL}}$} \\
\hline & $\mathbf{N}$ & $\overline{\text { UNI }}$ & BI & $\overline{\mathbf{N}}$ & $\overline{U N I}$ & BI \\
\hline \multirow{2}{*}{$\mathrm{r}_{\mathrm{T}, \mathrm{I}} \leq \mathbf{0 , 1 0}$} & \multirow{2}{*}{7.622} & 0,045 & 0,058 & \multirow{2}{*}{23} & 0,052 & 0,350 \\
\hline & & $(0,030)$ & $(0,038)$ & & $(0,041)$ & $(0,008)$ \\
\hline \multirow{2}{*}{$0,10<r_{\mathrm{T}, \mathrm{I}} \leq 0,30$} & \multirow{2}{*}{8.011} & 0,202 & 0,204 & \multirow{2}{*}{523} & 0,242 & 0,409 \\
\hline & & $(0,063)$ & $(0,064)$ & & $(0,051)$ & $(0,022)$ \\
\hline \multirow{2}{*}{$0,30<r_{\mathrm{T}, \mathrm{I}} \leq 0,50$} & \multirow{2}{*}{6.346} & 0,415 & 0,415 & \multirow{2}{*}{1.085} & 0,401 & 0,498 \\
\hline & & $(0,061)$ & $(0,062)$ & & $(0,056)$ & $(0,037)$ \\
\hline \multirow{2}{*}{$0,50<r_{\mathrm{T}, \mathrm{I}} \leq 0,70$} & \multirow{2}{*}{12.402} & 0,583 & 0,572 & \multirow{2}{*}{1.369} & 0,589 & 0,630 \\
\hline & & $(0,052)$ & $(0,053)$ & & $(0,052)$ & $(0,041)$ \\
\hline \multirow{2}{*}{$r_{T, P}>0,70$} & \multirow{2}{*}{306} & 0,757 & 0,749 & \multirow{2}{*}{33} & 0,810 & 0,814 \\
\hline & & $(0,072)$ & $(0,074)$ & & $(0,072)$ & $(0,064)$ \\
\hline
\end{tabular}

$\mathrm{N}=$ número de observações; $\mathrm{r}_{\mathrm{T}, \mathrm{I}}=$ acurácias relativas à análise uni-característica

Na Tabela 10 estão descritas as médias das acurácias encontradas em touros com 1 ou mais progênies com fenótipo para AOL no banco de dados e machos jovens que são candidatos a CEIP e os seus respectivos percentuais de mudança das acurácias médias entre as análises uni e bi-característica.

Tabela 10. Acurácias de touros com 1 ou mais progênies com fenótipo (AOL) no banco de dados e machos jovens (CEIP) nas análises uni e bi-característica e percentual de mudança das acurácias (\%).

\begin{tabular}{ccccc}
\hline CATEGORIAS & & UNI & BI & $\%$ \\
\hline \multirow{3}{*}{ Machos } & Geral & 0,440 & 0,487 & $9,7 \%$ \\
& sem VGM & 0,476 & 0,473 & $-0,6 \%$ \\
& com VGM & 0,398 & 0,504 & $26,6 \%$ \\
\hline \multirow{3}{*}{ Touros ( $\geq$ 1 progênie) } & Geral & 0,439 & 0,455 & $3,5 \%$ \\
& sem VGM & 0,422 & 0,426 & $0,9 \%$ \\
& com VGM & 0,524 & 0,593 & $13,2 \%$ \\
\hline \multirow{2}{*}{ Machos jovens (CEIP) } & Geral & 0,371 & 0,425 & $14,6 \%$ \\
& sem VGM & 0,370 & 0,363 & $-1,9 \%$ \\
& com VGM & 0,373 & 0,486 & $30,3 \%$ \\
\hline
\end{tabular}


De acordo com a tabela 10, nas categorias de machos aptos a serem utilizados na estação de monta, a inclusão dos valores genéticos moleculares nas análises contribuiu com aumento de 9,7\% quando comparado com as acurácias médias obtidas a partir da análise uni-característica. A categoria que teve o maior aumento das acurácias foram os "machos jovens (CEIP)" e que ainda não tinham nenhuma progênie, sendo que quando considerados todos os animais dessa categoria o aumento foi de $14,6 \%$ na acurácia.

Os animais com valores genéticos moleculares tiveram suas acurácias aumentadas nas análises bi-característica em todas as categorias avaliadas. Os animais sem valores genéticos moleculares apresentaram diminuição das acurácias na categoria "Machos jovens (CEIP)", provavelmente pelo peso que a informação dos marcadores tem como fonte de informação adicional, já que os mesmos não tinham progênie no banco de dados.

Estudo utilizando dados simulados para escore de marmoreio, com apenas $5 \%$ dos animais com fenótipos, correlação genética dos valores genéticos moleculares e da característica igual a 0,10 e diferentes proporções de animais da população genotipados demonstrou que os aumentos nas acurácias de seleção podem ser de $20,8 \%$ com 100\% dos animais genotipados e de $12,5 \%$ com apenas $25 \%$ dos animais genotipados quando comparados com o cenário sem nenhum animal genotipado. (SPANGLER; BERTRAND; REKAYA, 2007).

MacNeil et al. (2010) utilizando dados reais da raça Angus para marmoreio relataram que a inclusão dos valores genéticos moleculares não resultou em aumento considerável na acurácia média quando considerada a população total avaliada, porém teve efeito considerável nas acurácias de animais jovens e que tinham apenas os valores genéticos moleculares como fonte de informação, aumentando suas acurácias de 0,12 para 0,18.

Tang et al. (2011) reportaram que a inclusão de valores genéticos moleculares na avaliação genética de animais da raça Angus do Canadá aumentos na acurácia de $14,0 \%$ para peso ao nascimento, 15,6\% para peso a desmama, 0,14\% para efeito materno de peso a desmama, 30,0\% para peso adulto de vaca, 460,0 \% para peso aos 12 meses de idade e $91,6 \%$ para perímetro escrotal quando considerados todos os indivíduos da população avaliada, entretanto o número de fenótipos observados para as características 
peso aos 12 meses e perímetro escrotal era muito menor quando comparado com as outras características dessa análise. Após remover todos os animais sem fenótipos, os aumentos nas acurácias médias foram menores, sendo $12,1 \%$ para peso ao nascimento, 4,0\% para peso a desmama, $0,13 \%$ para efeito materno de peso a desmama, 19,0\% para peso adulto de vaca, $82,1 \%$ para peso aos 12 meses de idade e 10,5\% para perímetro escrotal

$\mathrm{Na}$ raça Nelore foram reportados aumentos nas acurácias de 56,0\% para idade ao primeiro parto, 36,0\% para produtividade acumulada, $62,0 \%$ para stayability e $19,0 \%$ para probabilidade de prenhez de novilhas aos 30 meses de idade dos machos jovens, candidatos ao teste de progênie, quando os valores genéticos moleculares das respectivas características foram incluídos na avaliação genética (LÔBO et al., 2011).

Os resultados obtidos nesse estudo são similares aos resultados encontrados nos trabalhos consultados que utilizaram metodologia de análise semelhante. A fonte de informação adicional dos valores genéticos moleculares contribuiu para aumentar as médias das acurácias quando comparadas com as medias das acurácias obtidas nas análises sem essa fonte de informação.

A inclusão dos valores genéticos moleculares na análise genética quantitativa promoveu maiores incrementos nas acurácias dos animais com menores acurácias, que geralmente são os animais mais jovens do rebanho, ou seja, os que não possuem informações de desempenho ou ainda não possuem um número significativo de progênies para o aumento das acurácias. No entanto, também houve contribuição como fonte adicional de informação dos touros com uma ou mais progênies, aumentando as acurácias em torno de $13,2 \%$ quando consideramos os touros genotipados.

\subsubsection{Espessura de gordura subcutânea (EGS)}

As estatísticas descritivas dos valores genéticos preditos de espessura de gordura subcutânea para os dois modelos de análise estão descritos na Tabela 11. 
Tabela 11. Número de observações e estatísticas descritivas dos valores genéticos preditos de espessura de gordura subcutânea (EGS) para análise uni-característica (UNI) e bi-característica (BI).

\begin{tabular}{cccccc}
\hline Modelo & $\mathbf{N}$ & $\boldsymbol{\mu}$ & $\mathbf{D P}$ & MIN & MAX \\
\hline UNI & 37.668 & 0,067 & 0,213 & $-1,088$ & 1,544 \\
BI & 37.668 & 0,056 & 0,203 & $-1,100$ & 1,400
\end{tabular}

$\mathrm{N}=$ número de observações; $\mu$ = média; $\mathrm{DP}=$ desvio padrão; $\mathrm{CV}=$ coeficiente de variação (\%); $M I N$ = valor mínimo observado; $M A X$ = valor máximo observado.

A média dos valores genéticos preditos pela análise bi-característica foi menor que a média dos valores genéticos preditos pela análise unicaracterística para EGS. Esse comportamento está relacionado á diminuição da variância genética aditiva nesse modelo.

O desvio padrão dos valores genéticos preditos pela da análise bicaracterística foi menor que da análise uni-característica, assim como os valores mínimo e máximo observados.

Essas diferenças apresentadas demonstram que a inclusão dos valores genéticos moleculares na análise pode alterar a média dos valores genéticos preditos, porém os valores mínimos e máximos também são alterados e para a característica EGS foram menores assim como a média quando comparados com os valores obtidos a partir da análise uni-característica.

O número de observações e as estatísticas descritivas das acurácias de EGS para os dois modelos de análise estão descritos na Tabela 12.

As acurácias demonstradas na Tabela 12 indicam que na média as acurácias foram semelhantes para as duas análises quando são considerados todos os animais. Os animais que tiveram os seus VGM $\mathrm{BI}$, o aumento foi de aproximadamente 0,08 , ou seja, aumento em torno de 17,5\% na média das acurácias. 
Tabela 12. Número de observações e estatísticas descritivas das acurácias de espessura de gordura subcutânea (EGS) para análise uni-característica (UNI) e bi-característica $(\mathrm{BI})$.

\begin{tabular}{ccccccc}
\hline Modelo & & $\mathbf{N}$ & $\boldsymbol{\mu}$ & $\mathbf{D P}$ & MIN & MAX \\
\hline \multirow{2}{*}{ UNI } & Geral & 37.668 & 0,339 & 0,213 & 0 & 0,98 \\
& sem VGM $_{\text {EGS }}$ & 34.635 & 0,330 & 0,216 & 0 & 0,98 \\
& com VGM & 3.033 & 0,441 & 0,144 & 0 & 0,96 \\
\hline \multirow{2}{*}{ BI } & Geral & 37.668 & 0,341 & 0,206 & 0 & 0,98 \\
& sem VGM & 34.635 & 0,326 & 0,206 & 0 & 0,98 \\
& com VGM & 3.033 & 0,518 & 0,093 & 0,33 & 0,95
\end{tabular}

$\mathrm{N}=$ número de observações; $\mu=$ média; $\mathrm{DP}=$ desvio padrão; $\mathrm{MIN}=$ valor mínimo observado; MAX = valor máximo observado.

Na Tabela 13 estão descritas as médias das acurácias encontradas nos animais agrupados de acordo com as faixas de acurácias da análise UNI.

Tabela 13. Número de observações, médias e desvios-padrão (entre parênteses) das acurácias de espessura de gordura subcutânea (EGS) por faixas de acurácia estimadas de acordo com a análise uni-característica para as análises uni-característica (UNI) e bi-característica (BI).

\begin{tabular}{|c|c|c|c|c|c|c|}
\hline \multirow{2}{*}{ Acurácias $\left(r_{T, 1}\right)$} & \multicolumn{3}{|c|}{ sem VGM $\mathrm{EGS}$} & \multicolumn{3}{|c|}{ com VGM EGS } \\
\hline & $\mathbf{N}$ & UNI & BI & $\mathbf{N}$ & UNI & BI \\
\hline \multirow{2}{*}{$r_{\mathrm{T}, \mathrm{I}} \leq \mathbf{0 , 1 0}$} & \multirow{2}{*}{7.830} & 0,042 & 0,056 & \multirow{2}{*}{28} & 0,056 & 0,335 \\
\hline & & $(0,029)$ & $(0,037)$ & & $(0,039)$ & $(0,005)$ \\
\hline \multirow{2}{*}{$0,10<\mathrm{r}_{\mathrm{T}, \mathrm{I}} \leq \mathbf{0 , 3 0}$} & \multirow{2}{*}{8.309} & 0,196 & 0,194 & \multirow{2}{*}{591} & 0,241 & 0,396 \\
\hline & & $(0,062)$ & $(0,063)$ & & $(0,049)$ & $(0,022)$ \\
\hline \multirow{2}{*}{$0,30<r_{\mathrm{T}, \mathrm{I}} \leq 0,50$} & \multirow{2}{*}{8.437} & 0,432 & 0,421 & \multirow{2}{*}{1.215} & 0,408 & 0,490 \\
\hline & & $(0,061)$ & $(0,058)$ & & $(0,059)$ & $(0,038)$ \\
\hline \multirow{2}{*}{$0,50<r_{\mathrm{T}, \mathrm{I}} \leq 0,70$} & \multirow{2}{*}{9.893} & 0,577 & 0,562 & \multirow{2}{*}{1.168} & 0,577 & 0,607 \\
\hline & & $(0,047)$ & $(0,048)$ & & $(0,046)$ & $(0,037)$ \\
\hline \multirow{2}{*}{$r_{\mathrm{T}, 1}>0,70$} & \multirow{2}{*}{166} & 0,781 & 0,768 & \multirow{2}{*}{31} & 0,796 & 0,793 \\
\hline & & $(0,076)$ & $(0,078)$ & & $(0,072)$ & $(0,066)$ \\
\hline
\end{tabular}

$\mathrm{N}$ = número de observações; $\mathrm{r}_{\mathrm{T}, \mathrm{I}}=$ acurácias relativas à análise uni-característica 
Todos os animais que tinham acurácias menores ou iguais 0,10 na análise uni-característica apresentaram aumento nas suas acurácias na análise

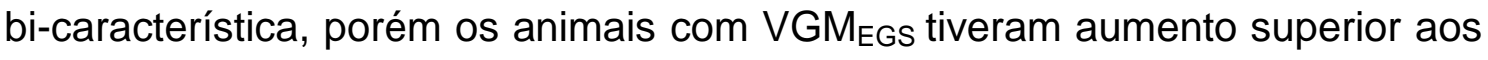
apresentados pelos animais sem VGMEGs. Esse aumento foi de aproximadamente 0,28 na média das acurácias para animais genotipados e de aproximadamente 0,014 na média das acurácias dos animais sem VGMEGs.

Os animais com $V_{G M} M_{E S}$ tiveram aumentos consideráveis até o grupo com acurácia menor ou igual 0,50 para análises utilizando o modelo bicaracterística.

$\mathrm{Na}$ Tabela 14 estão descritas as médias das acurácias encontradas em touros com uma ou mais progênies com fenótipo para EGS no banco de dados e machos jovens que são candidatos a CEIP e os respectivos percentuais de mudança das acurácias médias entre as análises uni e bi-característica.

Tabela 14. Acurácias de touros com 1 ou mais progênies com fenótipo (EGS) no banco de dados e machos jovens (CEIP) nas análises uni e bi-característica e percentual de mudança das acurácias (\%).

\begin{tabular}{ccccc}
\hline CATEGORIAS & & UNI & BI & $\%$ \\
\hline \multirow{3}{*}{ Machos } & Geral & 0,416 & 0,473 & $13,0 \%$ \\
& sem VGM & 0,445 & 0,437 & $-1,8 \%$ \\
& com VGM & 0,382 & 0,481 & $25,9 \%$ \\
\hline \multirow{3}{*}{ Touros ( $\geq$ 1 progênie) } & Geral & 0,422 & 0,433 & $2,5 \%$ \\
& sem VGM & 0,405 & 0,405 & $0,0 \%$ \\
& com VGM & 0,503 & 0,565 & $12,3 \%$ \\
\hline \multirow{2}{*}{ Machos jovens (CEIP) } & Geral & 0,355 & 0,403 & $11,9 \%$ \\
& sem VGM & 0,351 & 0,341 & $-2,8 \%$ \\
& com VGM & 0,359 & 0,465 & $29,5 \%$ \\
\hline
\end{tabular}

Dentre as categorias de machos aptos a serem utilizados na estação de monta, a inclusão dos valores genéticos moleculares nas análises contribuiu com aumento de $13,0 \%$ quando comparado com as acurácias médias obtidas a partir da análise uni-característica. A categoria que teve o maior aumento das acurácias foi a de "Machos jovens (CEIP)" que ainda não tinham nenhuma progênie, sendo que quando considerados todos os animais dessa categoria 0 aumento foi de $11,9 \%$ na acurácia.

Os animais com valores genéticos moleculares tiveram suas acurácias aumentadas nas análises bi-característica em todas as categorias avaliadas. 
Os animais sem valores genéticos moleculares apresentaram diminuição das acurácias na categoria de machos jovens, provavelmente pelo peso que a informação dos marcadores tem como fonte de informação adicional, já que os mesmos não tinham progênie no banco de dados.

Os animais sem valores genéticos moleculares para EGS tiveram uma diminuição de $1,8 \%$ na média das acurácias, sendo que a categoria de touros a média das acurácias continuou a mesma e para os machos jovens houve decréscimo de 2,8\%.

Esse comportamento é semelhante ao encontrado nas análises de AOL, onde os valores médios de acurácia encontrados na análise bi-característica são maiores que na análise uni-característica.

Esse comportamento também é semelhante aos relatados por autores que avaliaram o efeito da inclusão das informações dos marcadores moleculares em características de crescimento, reprodutivas e de marmoreio nas raças Angus e Nelore (LÔBO et al., 2011; MACNEIL et al., 2010; TANG et al., 2011).

As maiores alterações ocorreram nas acurácias dos animais mais jovens, ou seja, animais que tinham um menor número de informações para a predição do seu mérito genético. Também houve aumento nas acurácias obtidas a partir da análise bi-característica dos touros genotipados, onde os valores genéticos moleculares foram utilizados como fonte de informação adicional para a avaliação genética.

\subsubsection{Espessura de gordura na picanha (EGP)}

As estatísticas descritivas dos valores genéticos preditos de espessura de gordura na picanha para os dois modelos estão descritos na Tabela 15.

A média dos valores genéticos preditos pela análise bi-característica foi menor que a média dos valores genéticos preditos pela análise unicaracterística para EGP. O desvio padrão dos valores genéticos preditos pela análise bi-característica foi menor que da análise uni-característica, assim como os valores mínimo e máximo observados. 
Tabela 15. Número de observações e estatísticas descritivas dos valores genéticos preditos de espessura de gordura na picanha (EGP) para análise unicaracterística (UNI) e bi-característica (BI).

\begin{tabular}{cccccc}
\hline Modelo & $\mathbf{N}$ & $\boldsymbol{\mu}$ & $\mathbf{D P}$ & MIN & MAX \\
\hline UNI & 35.400 & 0,049 & 0,403 & $-1,852$ & 3,530 \\
BI & 35.400 & 0,026 & 0,391 & $-1,919$ & 3,186
\end{tabular}

$\mathrm{N}=$ número de observações; $\mu=$ média; $\mathrm{DP}=$ desvio padrão; $\mathrm{MIN}=$ valor mínimo observado; MAX = valor máximo observado.

O número de observações e as estatísticas descritivas das acurácias de EGS para os dois modelos de análise estão descritos na Tabela 16.

Tabela 16. Número de observações e estatísticas descritivas das acurácias de espessura de gordura na picanha (EGP) para análise uni-característica (UNI) e bi-característica (BI).

\begin{tabular}{ccccccc}
\hline Modelo & & $\mathbf{N}$ & $\boldsymbol{\mu}$ & $\mathbf{D P}$ & MIN & MAX \\
\hline \multirow{2}{*}{ UNI } & Geral & 35.400 & 0,338 & 0,224 & 0 & 0,99 \\
& sem VGM $_{\text {EGP }}$ & 32.367 & 0,327 & 0,226 & 0 & 0,99 \\
& com VGM & 3.033 & 0,465 & 0,162 & 0 & 0,97 \\
\hline \multirow{2}{*}{ BI } & Geral & 35.400 & 0,348 & 0,216 & 0 & 0,99 \\
& sem VGM & 32.367 & 0,328 & 0,213 & 0 & 0,99 \\
& com VGM & 3.033 & 0,563 & 0,089 & 0,39 & 0,97 \\
\hline
\end{tabular}

$\mathrm{N}=$ número de observações; $\boldsymbol{\mu}=$ média; $\mathrm{DP}=$ desvio padrão; $\mathrm{MIN}=$ valor mínimo observado; MAX = valor máximo observado.

A média das acurácias da análise bi-característica foi superior quando considerados todos os animais. Os animais que tinham a inclusão dos seus VGM ${ }_{E G P}$ no modelo de análise bi-característica apresentaram aumento de 0,098 na acurácia, ou seja, aumento em torno de 15,1\% na média das acurácias.

Na Tabela 17 estão descritas as médias das acurácias encontradas nos animais agrupados de acordo com as faixas de acurácia da análise UNI.

Todos os animais que tinham acurácias menores ou iguais 0,10 na análise uni-característica apresentaram aumento nas suas acurácias na análise

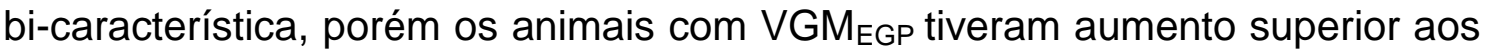
apresentados pelos animais sem VGM $\mathrm{VGG}_{\mathrm{EP}}$. Esse aumento foi de 
aproximadamente 0,34 na média das acurácias para animais genotipados e de aproximadamente 0,02 na média das acurácias dos animais sem $V G M_{E G P}$.

Tabela 17. Número de observações, médias e desvios-padrão (entre parênteses) das acurácias de espessura de gordura na picanha (EGP) por faixas de acurácia estimadas de acordo com a análise uni-característica para as análises uni-característica (UNI) e bi-característica (BI).

\begin{tabular}{|c|c|c|c|c|c|c|}
\hline \multirow{2}{*}{ Acurácias $\left(\mathbf{r}_{\mathrm{T}, \mathrm{l}}\right)$} & \multicolumn{3}{|c|}{ sem VGM $\mathrm{EGP}_{\mathrm{P}}$} & \multicolumn{3}{|c|}{ com VGM $\mathrm{EGP}$} \\
\hline & $\mathbf{N}$ & UNI & BI & $\mathbf{N}$ & UNI & BI \\
\hline \multirow{2}{*}{$\mathrm{r}_{\mathrm{T}, \mathrm{I}} \leq \mathbf{0 , 1 0}$} & \multirow{2}{*}{8.386} & 0,043 & 0,062 & \multirow{2}{*}{35} & 0,053 & 0,397 \\
\hline & & $(0,031)$ & $(0,046)$ & & $(0,039)$ & $(0,006)$ \\
\hline \multirow{2}{*}{$0,10<\mathrm{r}_{\mathrm{T}, \mathrm{I}} \leq 0,30$} & \multirow{2}{*}{6.966} & 0,206 & 0,211 & \multirow{2}{*}{523} & 0,238 & 0,446 \\
\hline & & $(0,061)$ & $(0,064)$ & & $(0,051)$ & $(0,019)$ \\
\hline \multirow{2}{*}{$0,30<\mathrm{r}_{\mathrm{T}, \mathrm{I}} \leq \mathbf{0 , 5 0}$} & \multirow{2}{*}{7.979} & 0,413 & 0,414 & \multirow{2}{*}{1.154} & 0,404 & 0,524 \\
\hline & & $(0,059)$ & $(0,061)$ & & $(0,056)$ & $(0,033)$ \\
\hline \multirow{2}{*}{$0,50<\mathrm{r}_{\mathrm{T}, \mathrm{I}} \leq \mathbf{0 , 7 0}$} & \multirow{2}{*}{8.433} & 0,598 & 0,580 & \multirow{2}{*}{1.228} & 0,609 & 0,641 \\
\hline & & $(0,054)$ & $(0,049)$ & & $(0,058)$ & $(0,036)$ \\
\hline \multirow{2}{*}{$\mathrm{r}_{\mathrm{T}, \mathrm{I}}>\mathbf{0 , 7 0}$} & \multirow{2}{*}{603} & 0,729 & 0,713 & \multirow{2}{*}{93} & 0,744 & 0,751 \\
\hline & & $(0,052)$ & $(0,055)$ & & $(0,069)$ & $(0,064)$ \\
\hline
\end{tabular}

$\mathrm{N}$ = número de observações; $\mathrm{r}_{\mathrm{T}, \mathrm{I}}=$ acurácias relativas à análise uni-característica

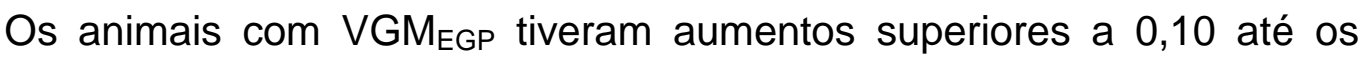
grupos com faixas de acurácia menor ou igual 0,50 para análises utilizando 0 modelo bi-característica.

Na Tabela 18 estão descritas as médias das acurácias encontradas em touros com uma ou mais progênies com fenótipo para EGP no banco de dados e machos jovens que são candidatos a CEIP e os respectivos percentuais de mudança das acurácias médias entre as análises uni e bi-característica.

Dentre as categorias de machos aptos a serem colocados na estação de monta, a inclusão dos valores genéticos moleculares nas análises contribuiu com aumento de $11,5 \%$ quando comparado com as acurácias médias obtidas a partir da análise uni-característica. A categoria que teve o maior aumento das acurácias foi a de "Machos jovens (CEIP)" que ainda não tinham nenhuma progênie, sendo que quando considerados todos os animais dessa categoria 0 
aumento foi de $20,9 \%$ na acurácia. Os animais com valores genéticos moleculares tiveram suas acurácias aumentadas na análise bi-característica em todas as categorias avaliadas.

Tabela 18. Acurácias de touros com 1 ou mais progênies com fenótipo (EGP) no banco de dados e machos jovens (CEIP) nas análises uni e bi-característica e percentual de mudança das acurácias (\%).

\begin{tabular}{ccccc}
\hline CATEGORIAS & & UNI & BI & $\%$ \\
\hline \multirow{3}{*}{ Machos } & Geral & 0,434 & 0,491 & $11,5 \%$ \\
& sem VGM & 0,464 & 0,459 & $-1,1 \%$ \\
& com VGM & 0,400 & 0,529 & $32,3 \%$ \\
\hline \multirow{3}{*}{ Touros ( $\geq$ 1 progênie) } & Geral & 0,417 & 0,436 & $4,5 \%$ \\
& sem VGM & 0,392 & 0,399 & $1,8 \%$ \\
& com VGM & 0,533 & 0,611 & $14,6 \%$ \\
\hline \multirow{2}{*}{ Machos jovens (CEIP) } & Geral & 0,373 & 0,451 & $20,9 \%$ \\
& sem VGM & 0,372 & 0,369 & $-0,8 \%$ \\
& com VGM & 0,374 & 0,513 & $37,2 \%$ \\
\hline
\end{tabular}

Os animais sem valores genéticos moleculares apresentaram diminuição das acurácias na categoria de machos jovens, provavelmente pelo peso que a informação dos marcadores tem como fonte de informação adicional, já que os mesmos não tinham progênie no banco de dados. Os animais sem valores genéticos moleculares para EGP tiveram uma diminuição de $1,1 \%$ na média das acurácias, sendo que para os machos jovens houve decréscimo de $-0,8 \%$. Entretanto, a média das acurácias aumentou em torno de 1,8\% na categoria de touros.

Para EGP, as acurácias tiveram comportamento semelhante ao encontrado nas análises de AOL e EGS, onde os valores médios de acurácia encontrados na análise bi-característica são maiores que na análise unicaracterística.

A inclusão dos valores genéticos moleculares na avaliação genética de pode ser uma alternativa para aumentar a acurácia dos valores genéticos preditos de animais jovens.

Segundo Tang et al. (2011), a utilização do modelo bi-característica tem duas vantagens práticas para programas de avaliação genética comercial. Primeiramente, sua implementação é simples e requer mínimas modificações nos programas para realizar a análise da avaliação genética (modificar modelo 
uni-característica para bi-característica). Outra vantagem seria a possibilidade de não precisar modificar os modelos desenvolvidos devido aos avanços das tecnologias de genotipagem (ex: painéis ou chips de maior densidade) e das metodologias de estimação dos efeitos dos SNPs que alterariam apenas os valores genéticos moleculares e não afetariam os modelos de análise para a seleção assistida por marcadores genéticos.

\subsection{Conflitos de seleção}

A ordenação dos animais baseado nos valores genéticos aditivos é uma importante estratégia de seleção de animais com alto mérito genético, pois a superioridade genética de um animal é dada pela superioridade do seu valor genético em comparação aos valores genéticos de outros animais da mesma avaliação genética.

$\mathrm{Na}$ figura 6 estão apresentados os coeficientes de correlação linear de Pearson entre os valores genéticos preditos pelas análises uni e bicaracterística e os coeficientes de correlação de Spearman entre a classificação dos animais com base no valor genético predito na análise unicaracterística e na análise bi-característica.

Os coeficientes de correlação de Pearson indicam elevada correlação linear positiva entre os valores genéticos preditos pela análise uni e bicaracterística para todas as características estudadas. Isso indica que houve alta similaridade entre os valores genéticos preditos pelo modelo bicaracterística e pelo modelo uni-característica.

Os coeficientes de correlação de postos de Spearman também foram elevados para todas as características avaliadas, demonstrando que existe alta correlação entre o ranqueamento dos animais com base no valor genético predito na análise uni-característica e na análise bi-característica. 


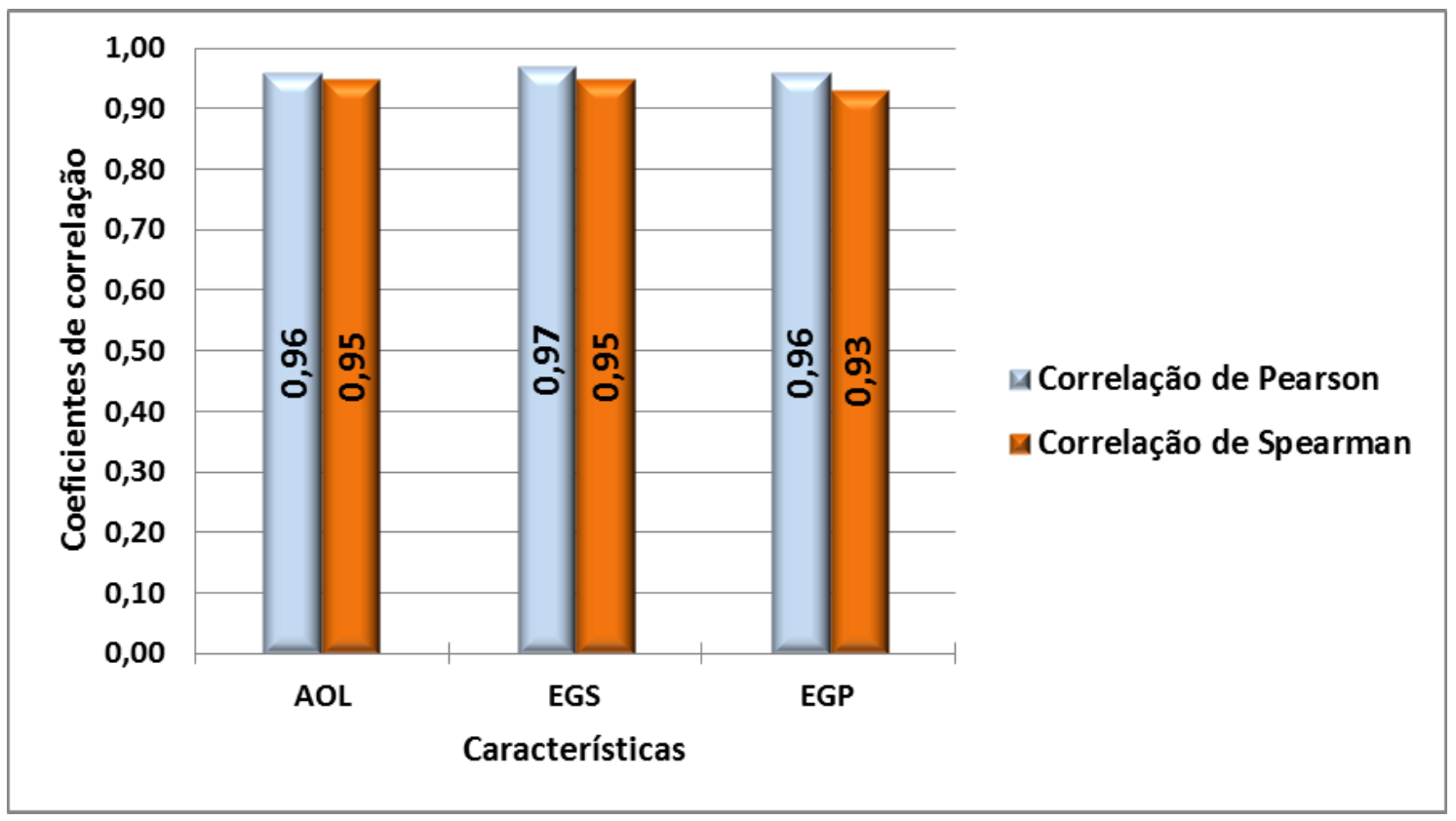

Figura 6. Estimativas dos coeficientes de correlação linear de Pearson e dos coeficientes de correlação de Spearman entre os valores genéticos preditos análises uni e bi-característica para as características avaliadas.

Nas Figuras 7 a 9 estão representadas as dispersões dos valores genéticos preditos de AOL, EGS e EGP obtidos pelas análises uni e bicaracterística. Foram considerados como animais selecionados os $20 \%$ melhores animais para cada característica tendo como base todo o rebanho avaliado. Os pontos de truncamento indicam os valores genéticos preditos mínimos para que um animal seja selecionado e foram representados pelas linhas pontilhadas. 


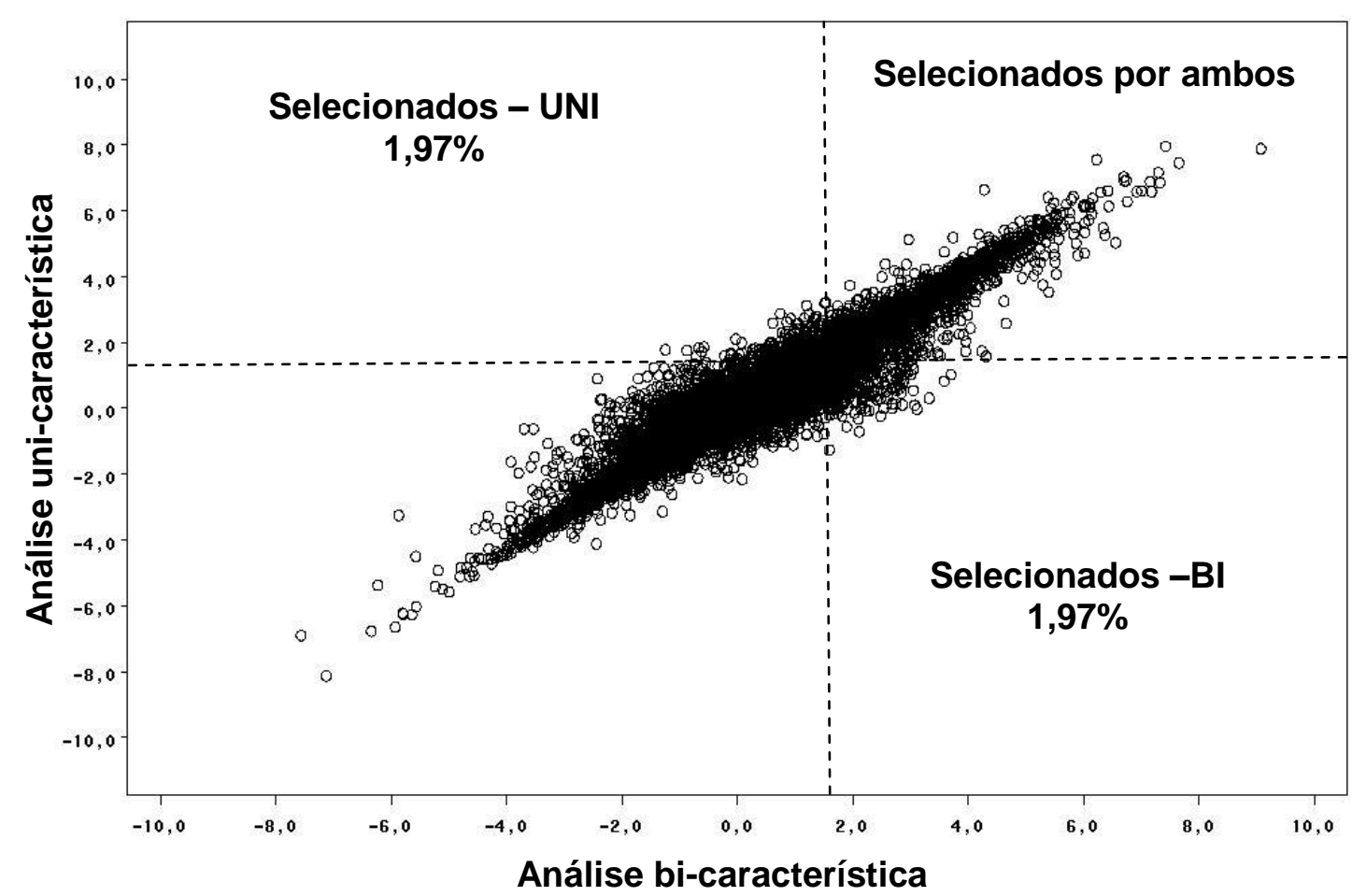

Figura 7. Dispersões dos valores genéticos preditos pelas análises uni e bicaracterística para área de olho de lombo (AOL) (linha pontilhada indica ponto de truncamento dos $20 \%$ melhores animais).

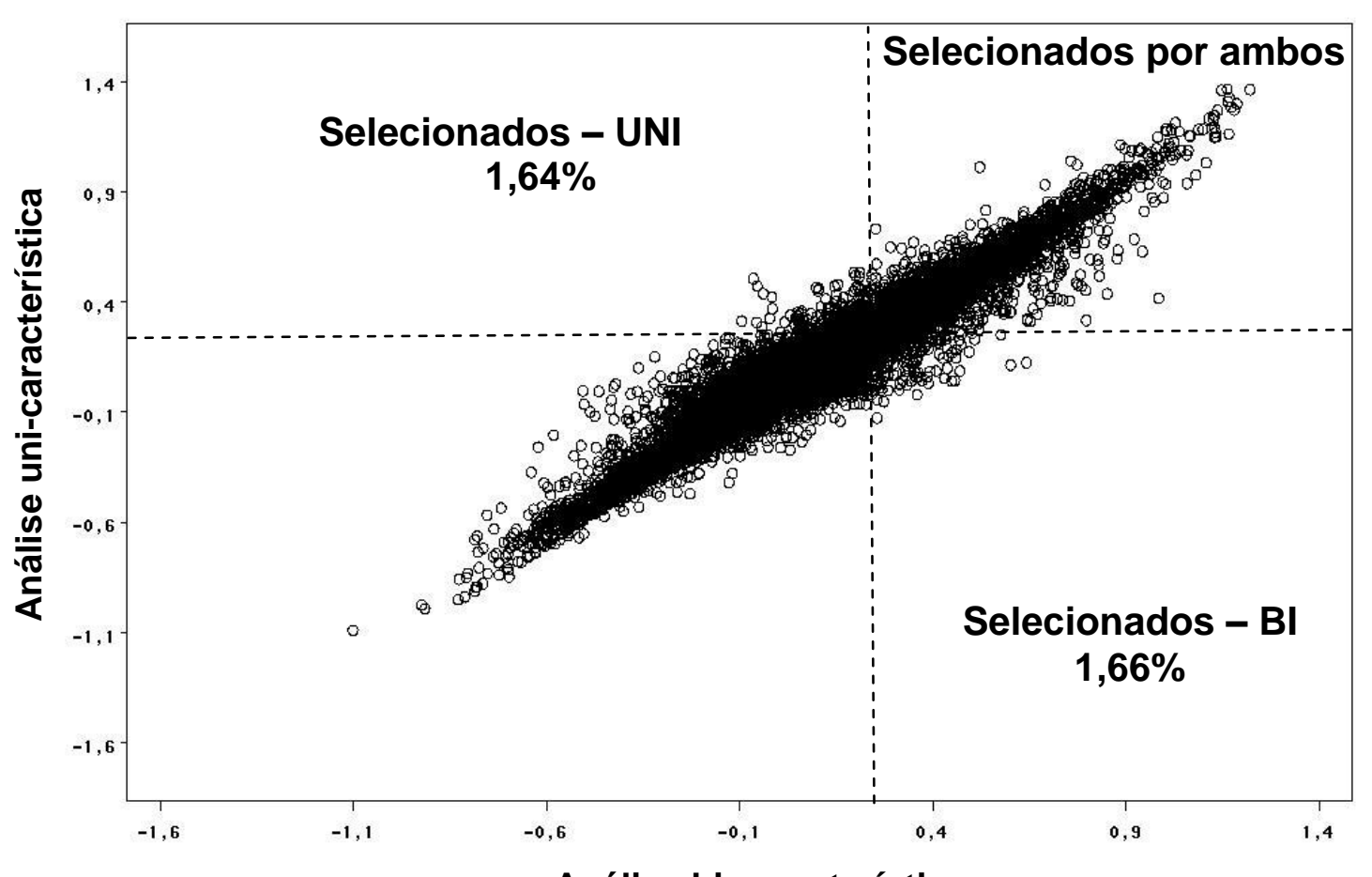

Análise bi-característica

Figura 8. Dispersões dos valores genéticos preditos (VGP) pelas análises uni e bi-característica para espessura de gordura subcutânea (EGS) (linha pontilhada indica ponto de truncamento dos $20 \%$ melhores animais). 


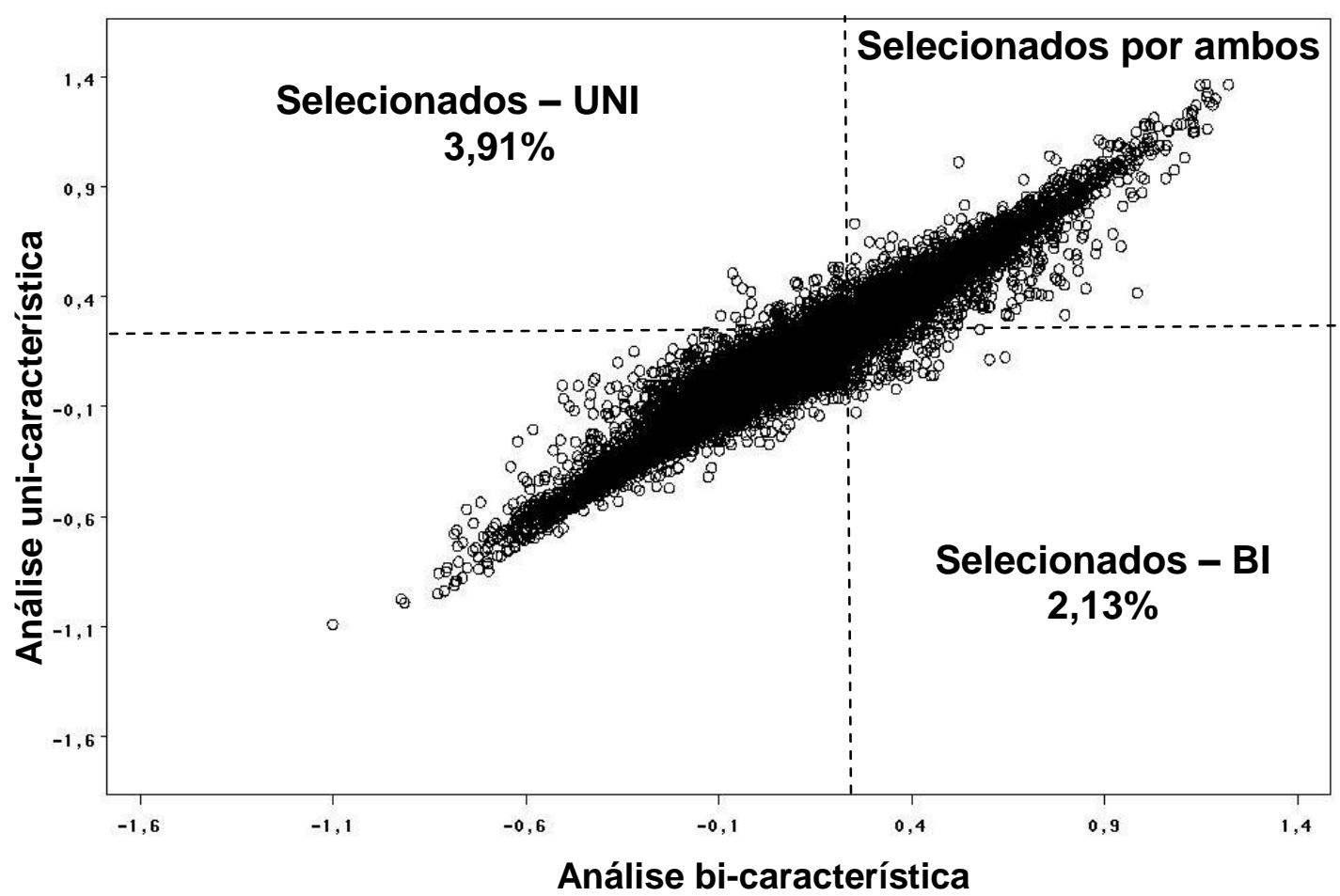

Figura 9. Dispersões dos valores genéticos preditos pelas análises uni e bicaracterística para espessura de gordura de picanha (EGP) (linha pontilhada indica ponto de truncamento dos $20 \%$ melhores animais).

Os conflitos de seleção indicam a proporção de animais selecionados por um critério e descartados por outro, através das divergências nas classificações dos animais pertencentes ao grupo dos $20 \%$ melhores avaliados. Os maiores conflitos de seleção foram observados para área de olho de lombo $(3,94 \%)$, seguido pela espessura de gordura $(3,69)$ de picanha e espessura de gordura subcutânea (3,30\%).

As tabelas 19, 20 e 21 apresentam os conflitos de seleção dentro das categorias geral que incluem todos os animais, somente os machos aptos à serem selecionados para estação de monta, touros que tenham uma ou mais progênies com fenótipo para a característica no banco de dados e apenas os machos jovens (CEIP) e não possuem nenhuma progênie. 
Tabela 19. Conflitos de seleção nas categorias dos animais selecionados pelos valores genéticos preditos pelas análises uni e bi-característica para área de olho de lombo (AOL).

\begin{tabular}{|c|c|c|c|c|}
\hline Categoria & & UNI (\%) & BI (\%) & Conflito (\%) \\
\hline \multirow{3}{*}{ Geral } & Todos & 1,97 & 1,97 & 3,94 \\
\hline & com VGM ${ }_{\mathrm{AOL}}$ & 7,09 & 12,17 & 19,26 \\
\hline & sem VGM ${ }_{A O L}$ & 1,55 & 1,12 & 2,67 \\
\hline \multirow{3}{*}{ Machos } & Todos & 4,78 & 4,78 & 9,56 \\
\hline & com VGM ${ }_{\mathrm{AOL}}$ & 5,81 & 10,06 & 15,87 \\
\hline & sem VGM & 3,92 & 0,36 & 4,28 \\
\hline \multirow{3}{*}{ Touros } & Todos & 3,57 & 1,84 & 5,41 \\
\hline & com VGM ${ }_{\mathrm{AOL}}$ & 5,98 & 8,31 & 14,29 \\
\hline & sem VGM ${ }_{A O L}$ & 3,06 & 0,49 & 3,55 \\
\hline \multirow{3}{*}{$\begin{array}{l}\text { Machos } \\
\text { Jovens }\end{array}$} & Todos & 5,68 & 6,97 & 12,65 \\
\hline & com VGM ${ }_{\mathrm{AOL}}$ & 5,78 & 10,40 & 16,18 \\
\hline & sem VGM ${ }_{A O L}$ & 5,49 & 0,13 & 5,62 \\
\hline
\end{tabular}

UNI (\%): proporção de animais selecionados apenas pelo valor genético predito pela análise uni-característica; $\mathrm{BI}(\%)$ : proporção de animais selecionados apenas pelo valor genético predito pela análise bi-característica; CONFLITO: proporção total de animais que apresentaram conflito de seleção.

A análise dos conflitos de seleção para $\mathrm{AOL}$ demonstraram que as discrepâncias entre as classificações são maiores para a categoria dos machos jovens. Os animais genotipados também apresentaram porcentagens superiores em todas as categorias quando comparados com seus pares não genotipados.

Tabela 20. Conflitos de seleção nas categorias dos animais selecionados pelos valores genéticos preditos pelas análises uni e bi-característica para espessura de gordura subcutânea.

\begin{tabular}{clccc}
\hline Categoria & & UNI (\%) & BI (\%) & Conflito (\%) \\
\hline \multirow{2}{*}{ Geral } & Todos & 1,64 & 1,66 & 3,30 \\
& com VGM & 7,91 & 9,07 & 16,98 \\
& sem VGM & 1,12 & 1,04 & 2,16 \\
\hline \multirow{2}{*}{ Machos } & Todos & 1,99 & 1,94 & 3,93 \\
& com VGM & 1,99 & 3,93 & 5,92 \\
& sem VGM & 1,96 & 0,27 & 2,25 \\
\hline \multirow{2}{*}{ Touros } & Todos & 1,27 & 0,52 & 1,79 \\
& com VGM & 2,66 & 2,33 & 4,99 \\
& sem VGM & & \\
\multirow{2}{*}{ Machos } & Todos & 0,97 & 0,14 & 1,11 \\
jovens & com VGM & 2,52 & 2,99 & 5,51 \\
& sem VGM & 1,86 & 4,24 & 6,10 \\
& s. & 3,83 & 0,51 & 4,34 \\
\hline
\end{tabular}

UNI (\%): proporção de animais selecionados apenas pelo valor genético predito pela análise uni-característica; $\mathrm{BI}(\%)$ : proporção de animais selecionados apenas pelo valor genético predito pela análise bi-característica; CONFLITO: proporção total de animais que apresentaram conflito de seleção. 
Tabela 21. Conflitos de seleção nas categorias dos animais selecionados pelos valores genéticos preditos pelas análises uni e bi-característica para espessura de gordura de picanha (EGP).

\begin{tabular}{ccccc}
\hline Categoria & & UNI (\%) & BI (\%) & Conflito (\%) \\
\hline \multirow{2}{*}{ Geral } & Todos & 1,85 & 1,84 & 3,69 \\
& com VGM & 7,25 & 8,41 & 15,66 \\
& sem VGM & 1,39 & 1,30 & 2,69 \\
\hline \multirow{2}{*}{ Machos } & Todos & 5,08 & 5,03 & 10,11 \\
& com VGM & 7,43 & 9,96 & 17,39 \\
& sem VGM & 3,11 & 0,90 & 4,01 \\
\hline \multirow{2}{*}{ Touros } & Todos & 3,91 & 2,13 & 6,04 \\
& com VGM & 2,66 & 2,33 & 4,99 \\
& sem VGM & 0,14 & 1,11 \\
\hline \multirow{2}{*}{ Machos } & Todos & 0,97 & 0,14 & 13,12 \\
jovens & com VGM & 5,94 & 7,18 & 18,05 \\
& sem VGM & 7,71 & 10,34 & 3,32 \\
\hline
\end{tabular}

UNI (\%): proporção de animais selecionados apenas pelo valor genético predito pela análise uni-característica; $\mathrm{BI}(\%)$ : proporção de animais selecionados apenas pelo valor genético predito pela análise bi-característica; CONFLITO: proporção total de animais que apresentaram conflito de seleção.

O comportamento dos conflitos de seleção para EGS (Tabela 20) e EGP (Tabela 21) mantiveram-se semelhantes aos encontrados para AOL (Tabela 19), em que as discrepâncias entre as classificações são maiores para a categoria dos machos jovens e animais genotipados que apresentaram porcentagens superiores em todas as categorias quando comparados com seus pares não genotipados.

Com base nos coeficientes de correlação de Pearson e de Spearman, nas análises dos conflitos de seleção observadas e considerando que os pontos de truncamento visaram selecionar apenas os $20 \%$ melhores machos aptos a entrarem na estação de monta, isto é, touros e candidatos a tourinhos de reposição, pode-se considerar que ocorrem importantes mudanças nos animais selecionados para os diferentes modelos de análise, principalmente no caso dos animais genotipados. Se considerarmos que os valores genéticos preditos pelo modelo bi-característica apresentam estimativas de acurácia superiores, sugere-se que essa abordagem seja considerada nas avaliações genéticas e na seleção de animais geneticamente superiores para as características AOL, EGS e EGP. 


\subsection{Ganho genético anual esperado}

A eficiência da seleção de um programa de avaliação genética é geralmente aferida pelo ganho genético anual esperado (ou taxa de mudança genética anual esperada). O ganho genético anual esperado é diretamente proporcional a três fatores: acurácia de seleção, intensidade de seleção e o desvio padrão dos valores genéticos aditivos, e é inversamente proporcional a um quarto fator: intervalos de gerações (BOURDON, 2000).

$\mathrm{Na}$ tabela 22 estão apresentadas as acurácias de seleção dos machos e fêmeas e desvios padrão genético aditivo de cada característica para cada cenário hipotético para cálculo do ganho genético anual esperado. Para os machos a intensidade de seleção utilizada foi de 1,4 (20\% melhores) e intervalo de gerações de 3,5 anos e para as fêmeas a intensidade de seleção foi de 0,8 (50\% melhores) e intervalo de gerações de 5 anos para as fêmeas.

Tabela 22. Acurácias de seleção dos machos e fêmeas utilizadas para o cálculo do ganho genético anual esperado para os diferentes cenários.

\begin{tabular}{cccc}
\hline CARACTERÍSTICAS & & UNI & BI \\
\hline \multirow{4}{*}{ AOL } & Machos & 0,440 & 0,487 \\
& Fêmeas & 0,356 & 0,356 \\
& $\widehat{\sigma}_{a}$ & 3,27 & 3,12 \\
\hline \multirow{4}{*}{ EGS } & Machos & 0,416 & 0,473 \\
& Fêmeas & 0,339 & 0,339 \\
& $\widehat{\sigma}_{a}$ & 0,52 & 0,48 \\
\hline \multirow{4}{*}{ EGP } & Machos & 0,434 & 0,491 \\
& Fêmeas & 0,338 & 0,338 \\
& $\widehat{\sigma}_{a}$ & 0,91 & 0,85 \\
\hline$\widehat{\sigma}_{a}:$ desvio padrão genético aditivo & &
\end{tabular}

$\mathrm{Na}$ tabela 23 estão apresentadas os ganhos genéticos anuais esperados para cada característica avaliada quando considerados apenas os resultados obtidos de acurácia dos animais jovens genotipados. 
Tabela 23. Ganho genético anual esperado ( $\Delta \mathrm{G} / \mathrm{ano})$ e porcentagem (\%) de mudança observada entre os modelos uni e bi-característica, considerando apenas machos jovens.

\begin{tabular}{lrcc}
\hline & $\boldsymbol{\Delta G} / \mathbf{a n O}_{\text {UNI }}$ & $\boldsymbol{\Delta G} /$ ano $_{\text {BI }}$ & $\%$ \\
\hline AOL (cm²/ano) & 0,347 & 0,355 & 2,4 \\
EGS (mm/ano) & 0,052 & 0,053 & 0,9 \\
EGP (mm/ano) & 0,094 & 0,096 & 1,9 \\
\hline
\end{tabular}

$\Delta$ G/ano: ganho genético anual esperado; \%: porcentagem de mudança observada utilizando os parâmetros dos diferentes modelos

Nesse caso não foi considerada a diminuição do intervalo de gerações, pois o objetivo foi verificar o efeito do aumento da acurácia de seleção dos machos nos ganhos genéticos anuais esperados para as características AOL, EGS e EGP.

$O$ ganho genético anual de maior aumento percentual foi para $A O L$ e o menor aumento percentual foi para EGS. EGS teve um aumento de apenas 0,9\% no ganho genético anual, e isso se deve à diminuição de $14,8 \%$ da variância genética aditiva na análise bi-característica quando comparada com a variância genética aditiva da análise uni-característica (maior proporção entre as características avaliadas) e pela menor proporção de aumento das estimativas de acurácia obtidas com a inclusão dos valores genéticos moleculares no modelo quando comparadas com as proporções obtidas por AOL e EGP.

É importante ressaltar que apenas $7 \%$ dos animais tinham valores genéticos moleculares para AOL, EGS e EGP, e mesmo assim, houve aumento no ganho genético anual esperado.

A inclusão dos valores genéticos moleculares na avaliação genética aumentou a média das acurácias dos animais e, consequentemente, aumentou a taxa de ganho genético anual para as três características estudadas. Se considerarmos que esses machos serão selecionados como touros e tourinhos de reposição e serão os responsáveis pela disseminação de material genético para todo o rebanho, os aumentos de $2,4 \%$ para AOL, 0,9\% para EGS e 1,9\% para EGP na taxa de ganho genético anual devem ser consideradas importantes. 
A seleção assistida por marcadores genéticos deve ser acompanhada ao longo das gerações nas populações em que for utilizada, já que diversos trabalhos com dados simulados têm demonstrado que a correlação genética entre os painéis de marcadores genéticos e os valores genéticos reais pode diminuir ao longo das gerações, devido à rápida fixação dos alelos favoráveis na população (DEKKERS, 2004; LANDE; THOMPSON,1990; SPANGLER; BERTRAND; REKAYA, 2007; VILLANUEVA et al., 1999; VERRIER, 2001).

A utilização dos valores genéticos moleculares nas avaliações genéticas, como ferramenta auxiliar de seleção, pode aumentar os ganhos genéticos anuais de programas de avaliação genética para as características de área de olho de lombo, espessura de gordura subcutânea e espessura de gordura na picanha na raça Nelore. 


\section{CONCLUSÃO E IMPLICAÇÕES}

De uma forma geral, a inclusão dos valores genéticos moleculares como característica correlacionada nos modelos de avaliação genética contribuiu para o aumento das médias das acurácias das estimativas dos valores genéticos preditos para AOL, EGS e EGP. Os maiores aumentos das acurácias foram observados nos animais genotipados, ou seja, que tinham os valores genéticos moleculares incluídos no banco de dados, principalmente, na categoria dos machos jovens genotipados. Entretanto, houve a diminuição das acurácias dos machos jovens não genotipados.

As maiores divergências na seleção dos animais foram observadas para os touros e machos jovens com valores genéticos moleculares para as caraterísticas, demonstrando que a inclusão dos efeitos dos marcadores genéticos na análise modificou a classificação dos animais e, consequentemente, uma proporção dos animais selecionados pela seleção assistida por marcadores divergiu da seleção realizada pela analise unicaracterística.

Os ganhos genéticos anuais esperados pela seleção assistida por marcadores genéticos para AOL, EGS e EGP foram superiores quando comparados com os ganhos genéticos anuais esperados pela seleção realizada pelos parâmetros da analise uni-característica.

Pelos resultados demonstrados nesse trabalho, a seleção assistida por marcadores genéticos utilizando os valores genéticos moleculares em modelos bi-característica junto com os fenótipos observados, tem grande potencial para aumentar as acurácias de seleção de animais jovens, tanto tourinhos de reposição quanto de novilhas, e consequentemente, o ganho genético dos rebanhos. Entretanto, sugere-se que as proporções das variâncias genéticas explicadas pelos valores genéticos moleculares sejam re-estimadas a cada ciclo de avaliação, já que a seleção de animais com maior número de alelos favoráveis é aumentada, podendo ocorrer a rápida fixação desses alelos favoráveis. 


\section{REFERÊNCIAS BIBLIOGRÁFICAS}

ABIEC. Associação Brasileira das Indústrias Exportadoras de Carne:

Estatística. 2012. Disponível em : <http://www.abiec.com.br>.

Acesso em: 20 mai. 2012.

ABCZ. Associação Brasileira de criadores dos ciradores de zebu: Revistas. 2011. Disponivel em: < http://www.abcz.org.br/Noticias/Revistas $>$. Acesso em: 20 mai. 2012.

ANUALPEC 2012. Anuário da pecuária brasileira. São Paulo, Instituto FNP e Argos comunicação, p. 21-23, 2012.

ARAUJO, F.R.C. The use of real-time ultrasound to estimate variance components for groth and carcass traits in Nelore cattle. 2003. $56 f$. Dissertação (Mestrado) - University of California, Davis, 2003.

BAUD, S. An evaluation of the use of ultrasound scanning to predict carcass traits in steers grain fed for the Japanese market. Australian Journal of Agriculture Research, Melbourne, v.49, n.1, p.147-52, 1998.

BARENDSE, W.S. et al. A genetic linkage map of the bovine genome. Nature Genetics, London, v.6, p.619-639, 1994.

BERG, R.T.; BUTTERFIELD, R.M. Nuevos Conceptos sobre el desarollo del ganado vacuno. Zaragoza: Acríbia, 1979. 279p.

BERGEN, R.D. et al. Prediction of len yield in yearling bulls using real-time ultrasound. Canadian Journal of Animal Science, Ottawa, v.76, p.305-11, 1996.

BISHOP, M.D. et al. A genetic linkage map for cattle. Genetics, Austin, v.136, p.619-639, 1994.

BOLDMAN, K.G. et al. A manual for use of MTDFREML: A set of program to obtain estimates of variances and covariances (DRAFT). Lincoln:

Department of Agriculture, Agricultural Research Service, 1995, 120p. 
BONILHA, S.F.M. Efeitos da seleção para peso pós-desmama sobre características de carcaça, rendimento de cortes e composição corporal de bovinos Nelore e Caracu. 2003. 55f. Dissertação (Mestrado) - Escola Superior de Agricultura Luiz de Queiroz, Piracicaba, 2003.

BOURDON, R.M. Biotechnology and animal breeding. In: BOURDON, R.M. Understanding animal breeding. New Jersey: Prentice Hall, 2000. p.440-46.

BUCHANAN, F. C. et al. Association of a missense mutation in the bovine leptin gene with carcass fat content and leptin mRNA levels. Genetics Selection Evolution, Paris, v. 34, p.105-16, 2002.

CAETANO, A.R. Marcadores SNP: conceitos básicos, aplicações no manejo e no melhoramento animal e perspectivas para o futuro. Revista Brasileira de Zootecnia. Viçosa, v.38, p.64-71, 2009.

CEPEA-USP. 2012. PIB Agro CEPEA-USP/CNA. Disponivel em: www.cepea.esalq.usp.br/pib/. . Acesso em: 20 mai. 2012.

CREWS, D.H.; MOORE, S.S.; ENNS, R.M. Optimizing traditional and marker assisted evaluation in beef cattle. In: $40^{\text {th }}$ Annual Reserch Symposium, 2008, Calgary, Canada. Proceedings... Raleigh: BIF, [2008] (CD-ROM).

CUCCO, D.C. Estudo genético quantitativo e molecular de características de crescimento e carcaça em bovinos da raça Nelore usando inferência bayesiana. 2010. 109f. Tese (Doutorado) - Faculdade de Zootecnia e Engenharia de Alimentos, Universidade de São Paulo, Pirassununga, 2010.

CURI, R.A. et al. Alternative genotyping method for single nucleotide polymorphism A2959G (AF159246) of the bovine CAST gene. Pesquisa Agropecuária Brasileira, Brasilia, v. 43, n. 5, p. 657-659, 2008.

DEKKERS, J.C.M. Commercial application of marker- and gene assisted selection in livestock: Strategies and lessons. Journal of Animal Science, Champaign, v.82, p.E313-E328, 2004.

DEKKERS, J.C.M.; HOSPITAL, F. The use of molecular genetics in improvement of agricultural populations. Nature Reviews Genetics, London, v. 3, p. 22-32, 2002. 
EUCLIDES FILHO, K. Melhoramento Genético no Brasil: fundamentos, história e importância. Campo Grande: Embrapa Gado de Corte, 1999. p.19-20.

FERNANDO, R.L.; GROSSMAN, M. Marker assisted selection using best linear unbiased prediction. Genetics Selection Evolution, Paris, v.21, p.467-477, 1989.

FERRAZ, J.B.S. et al. Association of single nucleotide polymorphisms with carcass traits in Nellore cattle. Genetics and Molecular Research, Ribeirão Preto, v.8, p.1360-1366, 2009.

FERRAZ, J.B.S.; FELICIO, P.E. Production systems - An example from Brazil. Meat Science, Barking, v. 84, p.238-243, 2010.

FIGUEIREDO, L.G.G. Estimativas de parâmetros genéticos de características de carcaças feitas por ultrassonografia em bovinos da raça Nelore. 2001. 67f. Dissertação (Mestrado) - Faculdade de Zootecnia e Engenharia de Alimentos, Universidade de São Paulo, Pirassununga, 2001.

FITZSIMMONS, C.J. et al. A potential association between the BM1500 microsatellite and fat deposition in beef cattle. Mammalian Genome, New York, v.9, p.432-34, 1998.

GELDERMANN, H. Investigation on inheritance of quantitative characters in animal by gene markers. 1. Methods. Theoretical and Applied genetics, Berlin, v.46, p.319-330, 1975.

GIANOLA, D. et al. Additive genetic variability and the Bayesian alphabet. Genetics, Austin, v. 183, n.1, p.347-363, 2009.

GREEN, R.D. ASAS Centennial Paper: Future needs in animal breeding and genetics. Journal of Animal Science, Champaign, v.87, p.793-800, 2009.

GODDARD, M.E. A mixed model for analyses of data on multiple genetic markers. Theoretical and Applied genetics, Berlin, v.83, p.878-886, 1992.

HABIER, D. et al. Extension of the Bayesian alphabet for genomic selection. BMC Bioinformatics, v. 12, p. 186, 2011. 
HARRIS, B.L.; JOHNSON, D.L.; SPELMAN, R.J. Genomic selection in New Zealand and the implications for national genetic evaluation. In: Interbull Meeting, 2008, Niagara Falls, Canada. Proceedings... Niagara Falls: Interbull, [2008] (CD-ROM).

HAYES, B.J. et al. Genomic selection in dairy cattle: progress and challenges. Jounal of Dairy Science, Champaign, v.92, p.433-443, 2009.

HEDRICK, H.B. Methods of estimating live animal and carcass composition. Journal of Animal Science, Champaign, v.57, p.1316-26, 1983.

HENDERSON, C.R. Best linear unbiased estimation and prediction under a selection model. Biometrics, Washington, v.31, p.423-447, 1975.

HERRING, W.; KEMP, D. The use of ultrasound technology in genetic selection decisions. In: XVII Range Beef Cow Simposium, 2001, Casper. Proceedings... Casper: Range Beef Cow Society, [2001] (CD-ROM).

IBGE. Instituto Brasileiro de Geografia e Estatística: Efetivo dos rebanhos bovinos em 2011. Disponível em :

$<$ http://www.ibge.gov.br/home/estatistica/economia/ppm/2011/tabelas_pdf/tab0 1.pdf>.

Acesso em: 20 mai. 2012.

IGENITY/NEOGEN CORPORATION. Igenity. 2012.

Disponível em : <http://www.igenity.com.br>.

Acesso em: 10 mai. 2012.

KACHMAN, S.D. Incorporation of marker scores into National Genetic

Evaluations. In: $9^{\text {th }}$ Genetic Prediction Workshop, 2008, Kansas City.

Proceedings... Kansa City:BIF, [2008] (CD-ROM).

LACORTE, G.A. et al. DGAT1 K232A polymorphism in Brazilian cattle breeds. Genetics and Molecular Research, Ribeirão Preto, v. 5, n. 3, p.475-482, 2006.

LANDE, R.; THOMPSON, R. Efficiency of marker assisted selection in the improvement of quantitative traits. Genetics, Austin, v.124, p.743-756, 1990.

LAI, E. et al. A 4-Mb high density single nucleotide polymorphism-based map around human APOE. Genomics, Los Altos, v.54, p.31-38, 1998. 
LIEFERS, S.C. et al. A missense mutation in the bovine leptin receptor gene is associated with leptin concentrations during late pregnancy. Animal Genetics, Oxford, v.35, p.138-41, 2004.

LÔBO, R.B. et al. Implementation of DNA markers to produce genomicallyenhanced EPDs in Nellore cattle. Acta Scientiae Veterinariae, Porto Alegre, v. 39, suppl 1, p s23-s27, 2011.

LUCHIARI FILHO, A. Pecuária de carne bovina. 1 ed. São Paulo: A. Luchiari Filho, 2000. 134p.

MACNEIL, M.D. et al. Genetic evaluation of Angus cattle for carcass marbling using ultrasound and genomic indicators. Journal of Animal Science, Champaign, v.88, p.517-522, 2010.

MEUWISSEN, T.H..; GODDARD, M.E. The use of marker haplotypes in animal breeding schemes. Genetics Selection Evolution, Paris, v. 28, p. 161-76, 1996.

MEUWISSEN, T.H; HAYES, B.J.; GODDARD, M.E. Prediction of total genetic value using genome-wide dense marker maps. Genetics, Austin, v.157, n.4, p.1819-1829, 2001.

MULLIS, K.B.; FALOONA, F.A. Specific synthesis of DNA in vitro via polymerase-catalyzed chain reaction. Methods in Enzymology, New York, v.155, p. 335-350, 1987.

NKRUMAH, J.D. et al. Association of a single nucleotide polymorphism in the bovine leptin gene with feed intake, feed efficiency, growth, feeding behaviour, carcass quality and body composition. Canadian Journal of Animal Science, Otawwa, v.84, p.211-19, 2004.

NKRUMAH, J.D. et al. Polymorphism in the bovine leptin promoter associated with serum leptin concentration, growth, feed intake, feeding behavior and measures of carcass merit. Journal of Animal Science, Champaign, v.83, p.20-8, 2005. 
OLERUP, O., ZETTERQUIST, H. HLA-DR typing by PCR amplification with sequence-specific primers (PCR-SSP) in 2 hours: an alternative to serological DR typing in clinical practive including donor-recipient matching in cadaveric transplantation. Tissue Antigen, London, v.39, p.225-35, 1992

OLIVEIRA, J.F.C.; HENKES, L.E. Marcadores moleculares em reprodução animal. In: GONSALVES, P.B.D.; FIGUEIREDO, J.R.; FREITAS, V.J.F. Biotécnicas aplicadas à reprodução animal. São Paulo: Varela Editora, 2002. p.261-79.

PEDROSA, V.B. Utilização de diferentes metodologias para avaliação genética de bovinos de corte. 2011. 87 f. Tese (Doutorado) - Faculdade de Zootecnia e Engenharia de Alimentos, Universidade de São Paulo, Pirassununga, 2011.

PFIZER. Pfizer Animal Genetics. 2011.

Disponível em : <http://www.pfizeranimalgenetics.com.br>. Acesso em: 11 nov. 2011.

PINTO, L.F.B. et al. Single nucleotide polymorphisms in CAPN and leptin genes associated with meat color and tenderness in Nellore cattle. Genetics and Molecular Research, Ribeirão Preto, v.10, p.2057-2064, 2011.

POMP, D. et al. Rapid comunnication: mapping of leptin to bovine chromosome 4 by linkage analysis of PCR-based polymorphism. Journal of Animal Science, Champaign, v.75, p.1427, 1997.

PRADO, C.S. et al. Comparação de diferentes métodos de avaliação da área de olho de lombo e cobertura de gordura em bovinos de corte. Ciência Animal Brasileira, Goiânia, v.5, p.141-149, 2004.

REVERTER, A. et al. Genetic analyses of live-animal ultrasound and abattoir carcass traits in Australian Angus and Hereford cattle. Journal of Animal Science, Champaign, v.78, p.1786-1795, 2000.

SAS Institute Inc. SAS/STAT 9.1. USER'S GUIDE. 2004. Disponível em: $<$ http://support.sas.com/documentation/onlinedoc/91pdf/sasdoc 91/stat ug 73 13.pdf> Acesso em: 10 set. 2011.

SILVA, S.L. Estimativa de características de carcaça e ponto ideal de abate por ultra-sonografia, em bovinos submetidos a diferentes níveis 
energéticos na ração. 2002. 80f. Dissertação (Mestrado) - FZEA-USP, Pirassununga, 2002.

SILVA, S.L. et al. Estimativa do peso e do rendimento de carcaça de tourinhos Brangus e Nelore, por medidas de ultra-sonografia. Revista Brasileira de Zootecnia, Viçosa, v.32, n.5, p.1227-35, 2003.

SILVA, S.L. et al. Estimativa da gordura de cobertura ao abate, por ultra-som, em tourinhos Brangus e Nelore. Revista Brasileira de Zootecnia, Viçosa, v.33, n.2, p.511-7, 2004.

SMITH, C.; SIMPSON, S.P. The use of genetic polymorphisms in livestock improvement. Journal of Animal Breeding and Genetics, Berlin, v.103, p.205-217, 1986.

SOLLER, M. The use of loci associated with quantitative traits in dairy cattle improvement. Animal Production, Bletchley, v.27, p.133-139, 1978.

SOUZA, F.R.P. et al. Assessment of DGAT1 and LEP gene polymorphisms in three Nelore (Bos indicus) lines selected for growth and their relationship with growth and carcass traits. Journal of Animal Science, Champaign, v.88, p.435-441, 2010.

SPANGLER, M.L.; BERTRAND, J.K.; REKAYA, R. Combining genetic test information and correlated phenotypic records for breeding values estimation. Journal of Animal Science, Champaign, v.85, p. 641-649, 2007.

STONE, R.T.; KAPPES, S.M. Two polymorphic microsatellites within an $18 \mathrm{~kb}$ genomic clone containing the bovine ob gene. Animal Genetics, Oxford, v.27, p.64, 1996.

SUGUISAWA, L. Ultra-sonografia para predição das características e composição da carcaça de bovinos. 2002. 70f. Dissertação (Mestrado) ESALQ/USP, Piracicaba, 2002.

TANG, G. et al. Developing marker-assisted models for evaluating growth traits in Canadian beef cattle genetic improvement. Livestock Science, v. 138, p. 6268, 2011. 
THALLMAN, R.M. et al. Estimation of the proportion of genetic variation accounted for by DNA Tests. In: $41^{\text {st }}$ Annual Research Symposium, 2009, Sacramento, California, EUA. Proceedings of Beef Improvement Federation [2009] (CD-ROM).

USDA. Statistics and Information. 2012. Disponivel em: < http://www.ers.usda.gov/topics/animal-products/cattle-beef/statisticsinformation.aspx > Acesso em: 20 mai. 2012.

UTRERA, A.R.; VAN VLECK, L.D. Heritability estimates for carcass traits of cattle: a review. Genetics and Molecular Research, Ribeirão Preto, v.3, p.380-394, 2004.

VAN ARENDONK, J.A.M. et al. Use of molecular data for genetic evaluation of livestock. 1999. Disponível em:

<http://www.agbiotechnet.com/proceedings/4_johan.pdf > Acesso em: 05 set. 2011.

VAN DER WERF, J. Seleção assistida por marcador. In: KINGHORN, B.; VAN DER WERF, J.; RYAN, M. Melhoramento animal: Uso de novas tecnologias. Piracicaba: FEALQ, 2006a. p.151-63.

VAN DER WERF, J. Valores genéticos estimados, DEPs e suas propriedades. In: KINGHORN, B.; VAN DER WERF, J.; RYAN, M. Melhoramento animal: Uso de novas tecnologias. Piracicaba: FEALQ, 2006b. p.79-98.

VERRIER, E. Marker assisted selection for the improvement of two antagonistic traits under mixed inheritance. Genetics Selection Evolution, Paris, v.33, p.17-38, 2001.

VILLANUEVA, B. et al. Potential benefit from using an identified major gene in BLUP evaluation with truncation and optimal selection. Genetics Selection Evolution, Paris, v.31, p.115-133, 1999.

VILLANUEVA, B. et al. Marker assisted selection with optimized contributions of candidates for selection. Genetics Selection Evolution, Paris, v.34, p.679703, 2002.

YOKOO, M.J. et al. Genetic associations between carcass traits measured by real-time ultrasound and scrotal circumference and growth traits in Nelore cattle. Journal of Animal Science, Champaign, v.88, p.52-58, 2010. 
WELLER, J.I. Quantitative trait loci analysis in animals. 1ed. CABI publishing, 2001, p31-32.

WILKINS, R.J.; DAVEY, H.W. A polymorphic microssatelite in the bovine leptin gene. Animal Genetics, Oxford, v.28, p.376, 1997.

WILLIAMS, R.E. Biceps femoris and rump fat as additional ultrasound measurements for predicting retail product and trimmable fat in beef carcass. Journal of Animal Science, Champaign, v.75, p.7-13, 1992. 